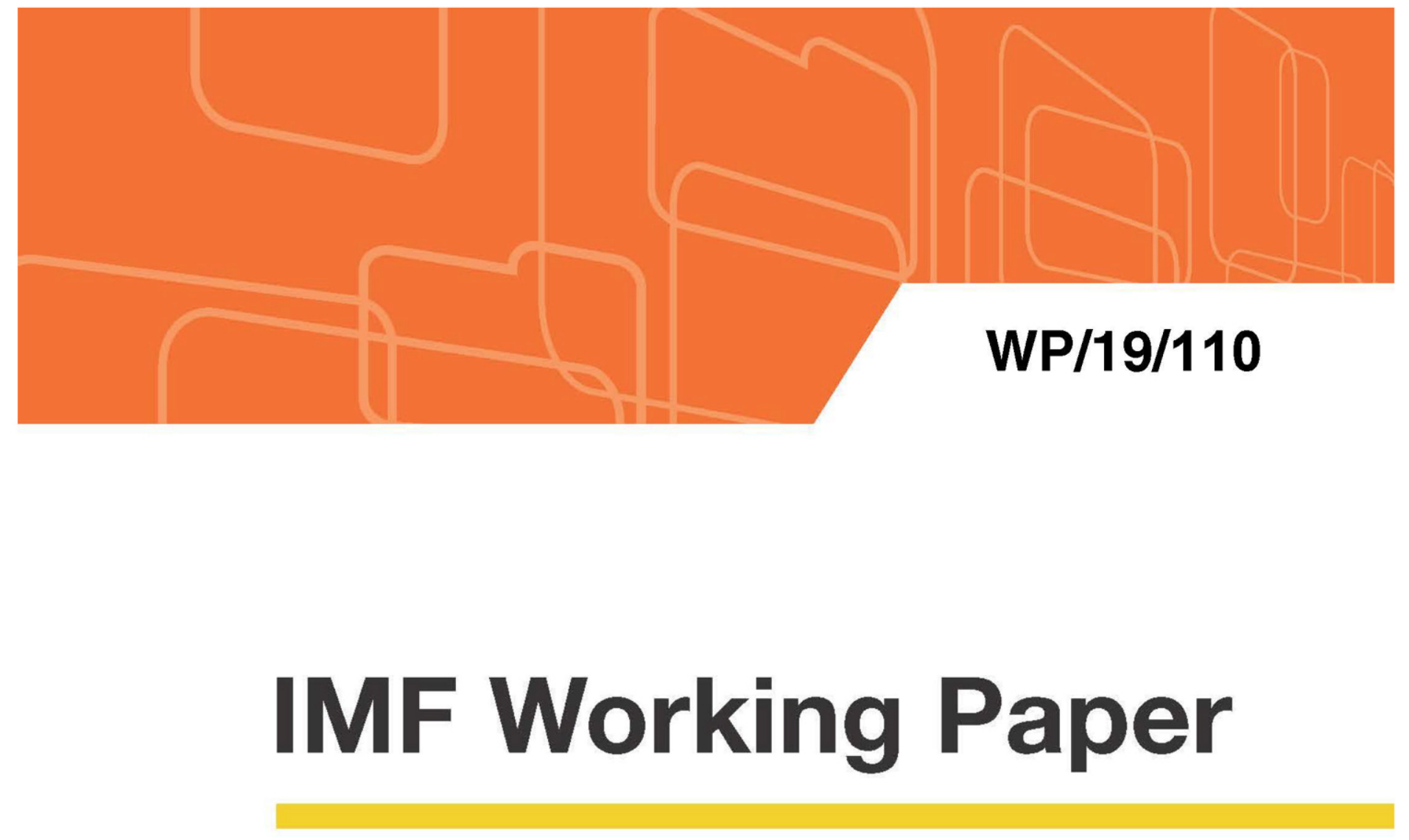

\title{
Government Wage Bill Management and Civil Service Reform in the Eastern Caribbean Currency Union
}

by Wayne Mitchell, Ronald James, and Ann Marie Wickham

IMF Working Papers describe research in progress by the author(s) and are published to elicit comments and to encourage debate. The views expressed in IMF Working Papers are those of the author(s) and do not necessarily represent the views of the IMF, its Executive Board, or IMF management.

I N T E R N A T I O N A L M O N E T A R Y F U N D 


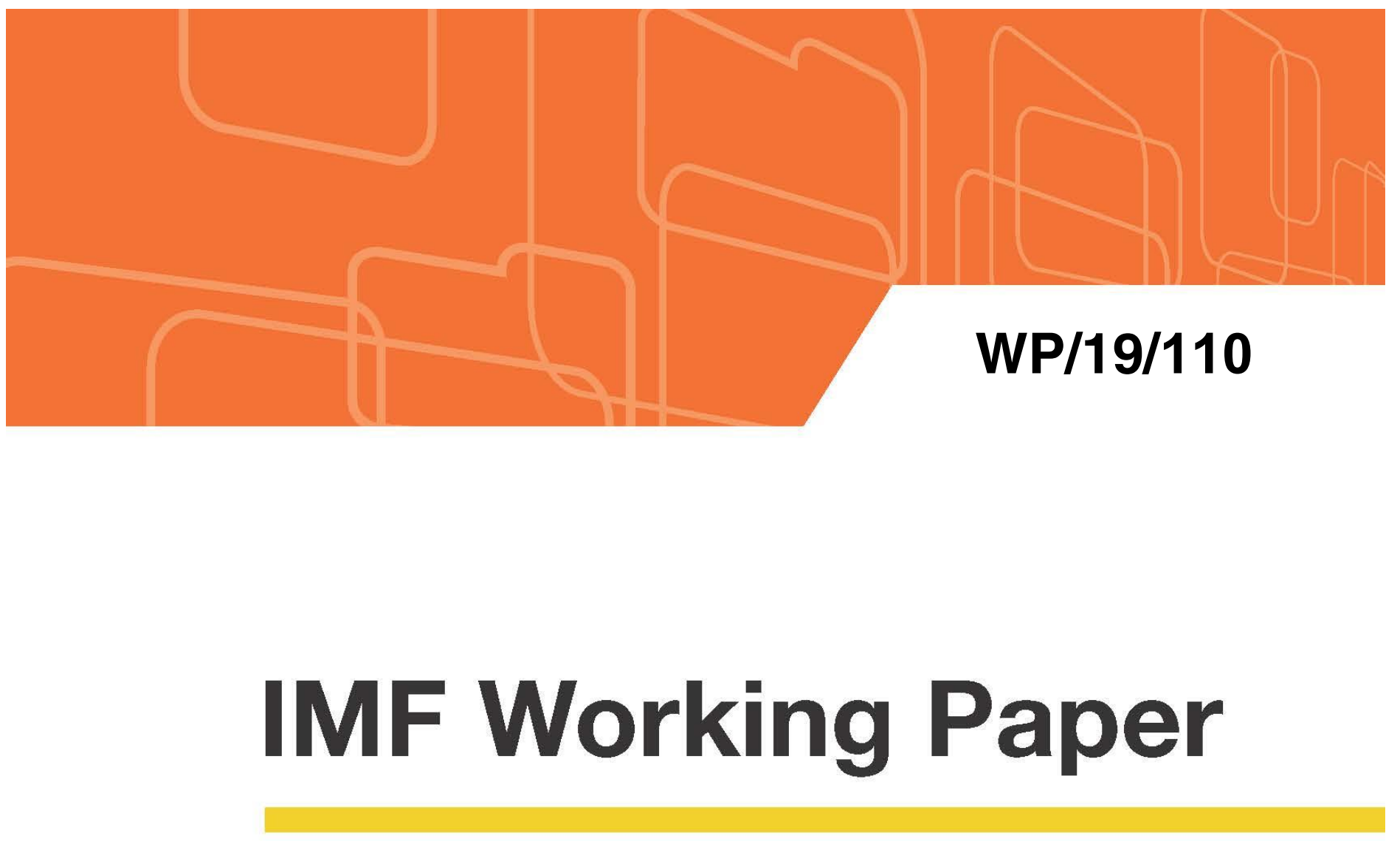

\section{Government Wage Bill Management and Civil Service Reform in the Eastern Caribbean Currency Union}

by Wayne Mitchell, Ronald James, and Ann Marie Wickham

IMF Working Papers describe research in progress by the author(s) and are published to elicit comments and to encourage debate. The views expressed in IMF Working Papers are those of the author(s) and do not necessarily represent the views of the IMF, its Executive Board, or IMF management.

$$
\text { I N T E R N A T | O N A L M O N E T A R Y F U N D }
$$




\title{
IMF Working Paper
}

Western Hemisphere Department

\section{Government Wage Bill Management and Civil Service Reform in the Eastern Caribbean Currency Union}

\author{
Prepared by Wayne Mitchell, Ronald James and Ann Marie Wickham*
}

Authorized for distribution by Sònia Muñoz

May 2019

IMF Working Papers describe research in progress by the author(s) and are published to elicit comments and to encourage debate. The views expressed in IMF Working Papers are those of the author(s) and do not necessarily represent the views of the IMF, its Executive Board, or IMF management.

\begin{abstract}
In this study, we assess the size of the government wage bill and employment in the member countries of the Eastern Caribbean Currency Union and their implications for fiscal sustainability and the adequacy of public service delivery. Over the period 2005 to 2015 their wage bill (as a percentage of GDP, government revenues and expenditures) is higher than in other small states notwithstanding recent efforts by governments to make it more manageable. The composition and distribution of employment is sub-optimal and is reflected in skills mismatches contributing to inefficiencies in public service delivery. Using a dynamic fixed-effects panel, we find that wage bill growth reflects the expansion of government activities to speed up economic and social development and that wage bill spending is procyclical in good times but is rigid during downturns. Finally, we identify the main institutional and legal reforms needed to improve wage bill management and public service efficiency.
\end{abstract}

JEL Classification Numbers: H50, H53, J30, M50

Keywords: Public Wage Bill, Fiscal Sustainability, Employment, Institutional Reforms, ECCU

Author's E-Mail Address: amitchel12@imf.org; jamesr@caribank.org; awickham@imf.org.

* We would like to thank Trevor Alleyne, Sònia Muñoz, Michael Baptiste, and participants at the seminar series of the Western Hemisphere Department of the IMF for helpful comments. 


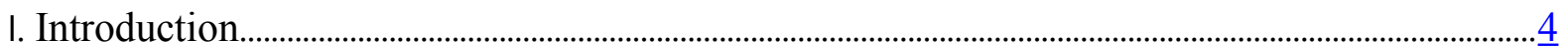

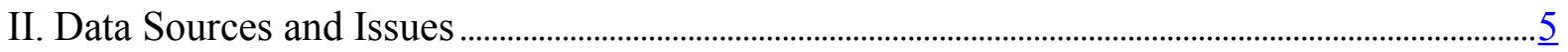

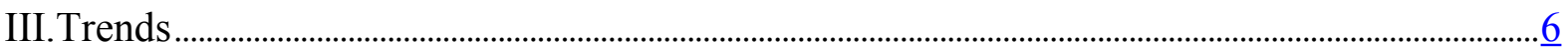

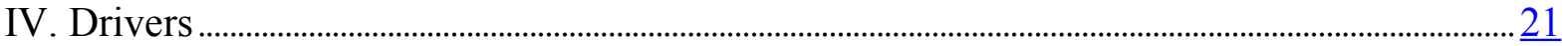

V. Wage Bill Management and Public Sector Reforms ........................................................................24

VI. Considerations for Reforms …………………….................................................................................. 27

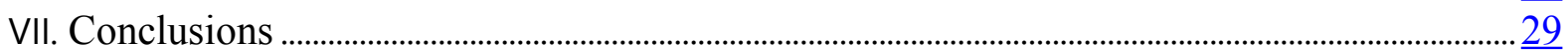

Boxes

1. Assessing Efficiency in Secondary School Education............................................... 18

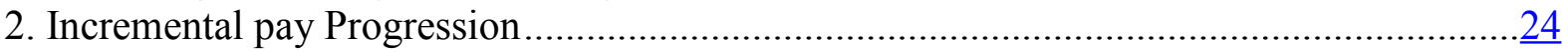

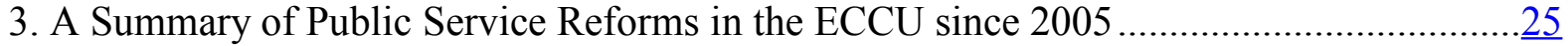

Figures

1. Average Government Wage Bill Spending 2005-2015 .......................................

2. Government Wage Bill Spending in Selected Small States in 2015 ...............................

3. Government Wage Bill Spending in ECCU Countries.............................................10

4. Price and Employment Effect on the Wage Bill since beginning Year.............................12

5. Employment by Function of Government per Population .............................................19

Tables

1. Selected Indicators on Education in 2015 ......................................................................

2. Model Results: Econmic Growth and Wage Expenditure ............................................ $\frac{22}{24}$

3. Model Results: Fiscal Balance and Wage Expenditure .................................................24

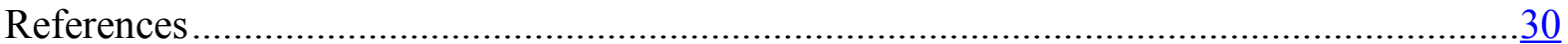




\section{Introduction}

The wage bill is the largest government outlay and the government is the single largest employer in the member countries of the Eastern Caribbean Currency Union (ECCU). ${ }^{1,2}$ The high wage bill partially reflects diseconomies of scale in the provision of public services in small states and political economy considerations. ${ }^{3}$ There are fixed costs in creating public institutions and providing critical services, such as public defense and security, health, education, public works, and quasi social assistance and support. These public services must be provided independent of population size. Consequently, the cost is higher per capita.

Notwithstanding the diseconomies of scale argument, the significance of the wage bill and government employment raises concerns about fiscal sustainability and the adequacy of public service delivery. This study follows the approach taken by the IMF (2016a) to assess wage bill and employment trends in the ECCU over the period 2005 to 2015 relative to comparators, including small states. ${ }^{4}$ On average, the wage bill (in GDP terms) and government employment in ECCU countries is around the median for small states and advanced economies, but higher than that of emerging markets and low income developing countries (LIDCs). Using annual employment and wage bill data for the period 2005 to 2015, we estimate the relative contributions of employment and price effects on the wage bill using a Laspeyre index and construct a real wage index. The findings indicate that average real wage growth exceeded the growth in real per capita GDP over the comparable period, implying, ceteris paribus, that government wage growth outpaced productivity growth. We then analyze the composition of government employment in the ECCU and conclude that the composition and distribution of employment is sub-optimal, reflected in skills mismatches, and contributes to inefficiency in public service delivery.

In assessing the drivers of the wage bill, we complement the work of Eckardt and Mills (2014) and IMF (2016a) and examine the impact of the (short-run) business cycle on wage bill spending and the fiscal position; and the long-run effects of economic growth on the wage bill. In the short-term, wage bill spending is asymmetric, increasing strongly during good times, but not significantly declining during economic downturns and contributing to deteriorating fiscal positions. Regarding the latter, we find that wage bill spending as a share of GDP expands with economic development and likely reflects the expansion of government activities for economic and social development.

ECCU governments have had varying degrees of success over the past decade in reducing the size of the wage bill and improving wage bill management and employment. We review and

\footnotetext{
${ }^{1}$ The government wage bill refers to outlays of the central government, government agencies and local governments that are reflected in the government's budget but excludes state-owned enterprises.

${ }^{2}$ For the purposes of the paper these comprise the six sovereign countries: Antigua and Barbuda, Dominica, Grenada, St. Kitts and Nevis, St. Lucia, St. Vincent and the Grenadines and excludes the two British Overseas Territories of Anguilla and Montserrat.

${ }^{3}$ Small states are defined as sovereign states with populations less than 1.5 million (Joint Task Force Report on Small States of the Commonwealth Secretariat and World Bank, 2000). ECCU countries, with populations of less than 200,000 - the smallest has a population of 50,000, are microstates.

${ }^{4}$ See International Monetary Fund (2016), "Managing Government Compensation and Employment-Institutions, Policies, and Reform Challenges," Washington, DC.
} 
complement the literature on country experiences, Soverall (2015), Sutton (2008), and Kitchen (1994) on selected Caribbean countries, and Browne (2010) on Antigua \& Barbuda; and identify the main elements of institutional and legal reforms needed to improve wage bill management and public service efficiency in the ECCU. Legal reforms supported by functional reviews, human resource (HR) management audits and adequate information management systems would be critical to improving HR management capacities and planning as well as facilitating the right-sizing of the civil service. A supporting framework to measure, monitor and evaluate productivity could be used to improve public service delivery and facilitate performance-based compensation.

The rest of the paper is organized as follows. Section II describes data sources and issues. Section III discusses the trends in the wage bill and employment since 2005 while section IV examines the key drivers of these trends including cyclical and structural factors. Section V examines legal and institutional deficiencies and summarizes governments' experience with wage bill management while Section VI discusses the main reform options to manage the wage bill in the medium term and to monitor government productivity and efficiency. Section VII concludes.

\section{Data Sources and Issues}

This section presents the data used in this paper. The IMF's World Economic Outlook (October 2016) database was used for constructing the wage bill indicators and the econometric analysis. Data on government employment (including education, health, and public safety) are of varied coverage and were obtained from country budget and other documents.

\section{Data Sources}

The main sources of data used in the analysis, tables and charts are as follows:

\begin{tabular}{|l|l|l|l|}
\hline \multicolumn{3}{|c|}{ Table 1: Source and Data Type for ECCU Countries } \\
\hline \multicolumn{1}{|c|}{ Data/Variable } & Periodicity & \multicolumn{1}{c|}{ Coverage } & \multicolumn{1}{c|}{ Source } \\
\hline $\begin{array}{l}\text { Wage Bill, GDP, Government } \\
\text { Revenue, Government } \\
\text { Expenditure, CPI }\end{array}$ & Annual & 2005 to 2015 & World Economic Outlook \\
\hline $\begin{array}{l}\text { Central Government } \\
\text { Employment }\end{array}$ & Annual & 2005 to 2015 & $\begin{array}{l}\text { Country Authorities - Ministry of } \\
\text { Finance and Budget documents }\end{array}$ \\
\hline $\begin{array}{l}\text { Employment Apprenticeship } \\
\text { Programs }\end{array}$ & Annual & 2014 & $\begin{array}{l}\text { Country Authorities - Ministry of } \\
\text { Finance and Budget documents }\end{array}$ \\
\hline $\begin{array}{l}\text { Education, Health, and Public } \\
\text { Safety Indicators }\end{array}$ & Annual & $\begin{array}{l}2015 \text { (or latest } \\
\text { prior data) }\end{array}$ & $\begin{array}{l}\text { Country Authorities, Caribbean } \\
\text { Development Bank, Organization of } \\
\text { East Caribbean States Commission, } \\
\text { UNESCO, World Bank }\end{array}$ \\
\hline Annual Wage by Industry & Monthly & 2014 & $\begin{array}{l}\text { Country Social Security Boards and } \\
\text { National Insurance Schemes }\end{array}$ \\
\hline
\end{tabular}




\section{Data Issues}

Wage bill data for the ECCU varies over the period as countries transitioned from the Government Financial Statistics Manual 1986 (GFSM86) methodology for the compilation of accounts to the improved GFSM2001 or GFSM 2014 methodologies. ${ }^{5}$ Consequently, comparability among countries within and outside the ECCU has limitations.

Disaggregated data of the components of wages or its distribution to facilitate the examination of pay policies of different employee groups are either unavailable or not available for extended periods because of inadequate personnel management and payroll reporting. ${ }^{6}$ Similarly, data on the wages of daily paid or temporary workers or the amount and distribution of incremental pay were not available from the wage bill in many of the countries.

Aggregate government employment data (by established and non-established categories) are generally available from 2005 in most countries except Dominica and Grenada. ${ }^{7}$ Data on daily paid, short-term employees, and project-related employment costs were not always distinguishable for most of the countries neither was the length of time that they were employed. Employee data disaggregated by Classification of the Function of Government (COFOG) were not standardized and classification by administrative function had to be used as proxies. The number of established employees in each grade, as well as the total remuneration per grade, were available for all countries. However, data on non-established employees disaggregated by COFOG or administrative function were available only in a few countries. Lastly, job categories are not standardized across countries. Improving personnel management systems to record and monitor staff numbers and composition (age, grade, positions, qualifications, etc.), job classifications, and staff skills as well as making the collated data available would improve analysis, fiscal transparency and cross-country comparisons. Data were obtained primarily from Ministries of Finance.

\section{Trends}

This section compares the government wage bill in ECCU countries with other country groups and assesses the contribution of staffing and pay policies on the evolution of the wage bill over the 2005 - 2015 business cycle. It then examines the size and composition of government employment and assesses issues of efficiency in public service delivery. The section concludes with an assessment of employee compensation.

\footnotetext{
${ }^{5}$ Antigua \& Barbuda has used GFSM2001 since 2006 while most countries adopted it later. Grenada and St. Lucia adopted GFSM2014 in 2016. In Grenada, the wage bill increased by 0.9 percentage points of GDP in 2016 following the classification of accounts in accordance with Grenada GFSM 2014.

${ }^{6}$ For instance, annual disaggregated wage bill by Classification of the Functions of Government (COFOG) and grade category and job title for established employees and non-established employees were available for Antigua \& Barbuda, but limited to established employees for Dominica, St. Kitts \& Nevis and St. Lucia, and unavailable for the others.

${ }^{7}$ Non-established employee data for Grenada are not available prior to 2013.
} 


\section{Government Wage Bill}

The wage bill of ECCU governments averages 10.1 percent of GDP, about the same size as those in other Small Island Developing States (SIDS), the region's comparator, but higher in percentage of expenditure (33.8) and revenue (38.1) - Figures 1 and $2 .{ }^{8}$ In most cases average wage costs of commodity-based Caribbean countries are lower than that of the ECCU and other tourism-based economies which tend to be economically smaller. St. Vincent \& the Grenadines stands out since three indicators in 2015 were above the average of SIDS (Figure 2 ). The wage bill indicators in ECCU countries also exceed those in other per capita groups advanced economies, emerging markets and LIDCs.

Small states have larger governments for several reasons. Because of their size, they have high per capita fixed costs in creating public institutions and providing critical services such as public defense and security, health, education, public works, and quasi social assistance and support. Medina Cas and Ota (2008) state that these public services must be provided independent of population size, resulting in diseconomies of scale and higher per capita costs in small states. ${ }^{9}$ They find that both government size and the public wage bill (both as a percentage of GDP) are negatively related to country size and that the relationship is statistically significant. Rodrik (1998) suggests that small open economies are more susceptible to trade volatility - for instance, the loss of EU preferences for agricultural products, high susceptibility to natural disasters - than larger countries and that a larger government sector in these countries helps mitigate the volatility. The World Bank (2005) also notes that countries, like those in the Caribbean, with strong voice and governance and associated strong democracies, tend to have larger government sectors, for example to provide basic education and health, as well as infrastructure. In countries beset with high debt burdens, low grant financing, and deteriorating physical infrastructure, the high wage bill to expenditure and revenue indicators suggests that other expenditures for the delivery of public services, asset maintenance and capital expenditures are underfunded or crowded out.

\footnotetext{
${ }^{8}$ For the purposes of the study ECCU averages relate to simple average of all the countries.

${ }^{9}$ Antigua \& Barbuda (2), St. Kitts \& Nevis, Grenada (3), and St. Vincent \& the Grenadines (9 inhabited islands and cays) would face additional costs of providing public services to relatively small populations dispersed over 2 or more islands.
} 


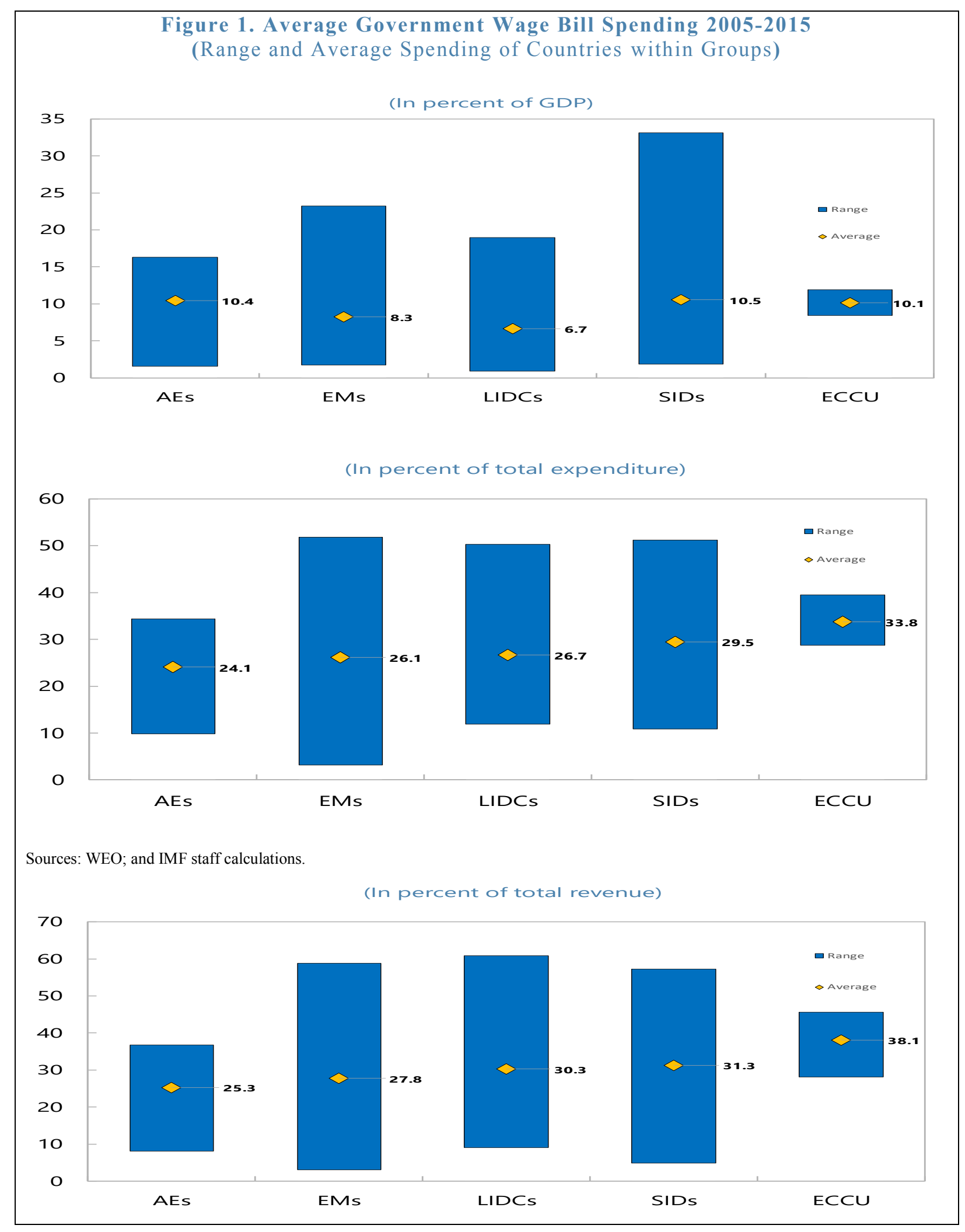




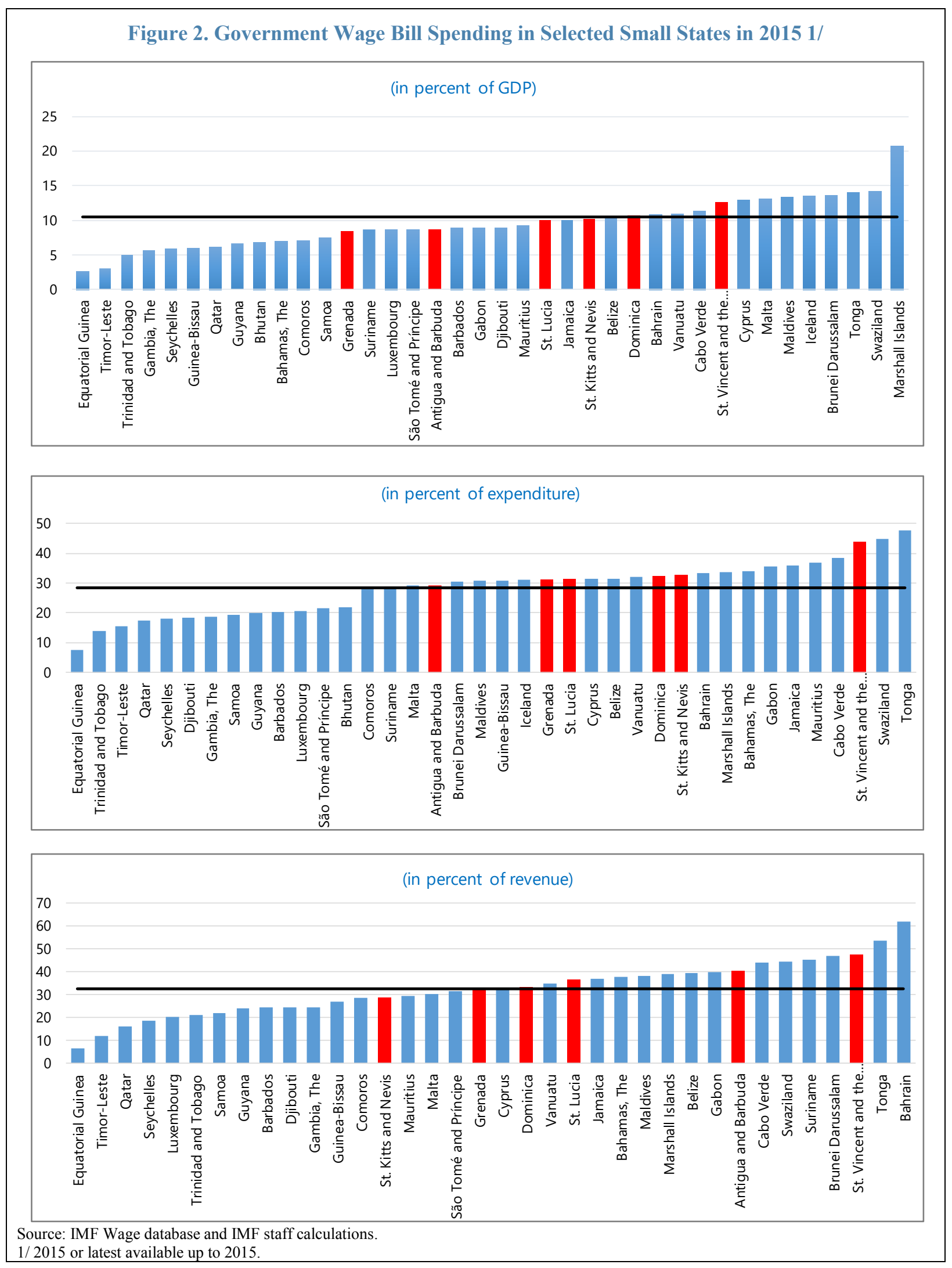


Figure 3. Government Wage Bill Spending in ECCU Countries
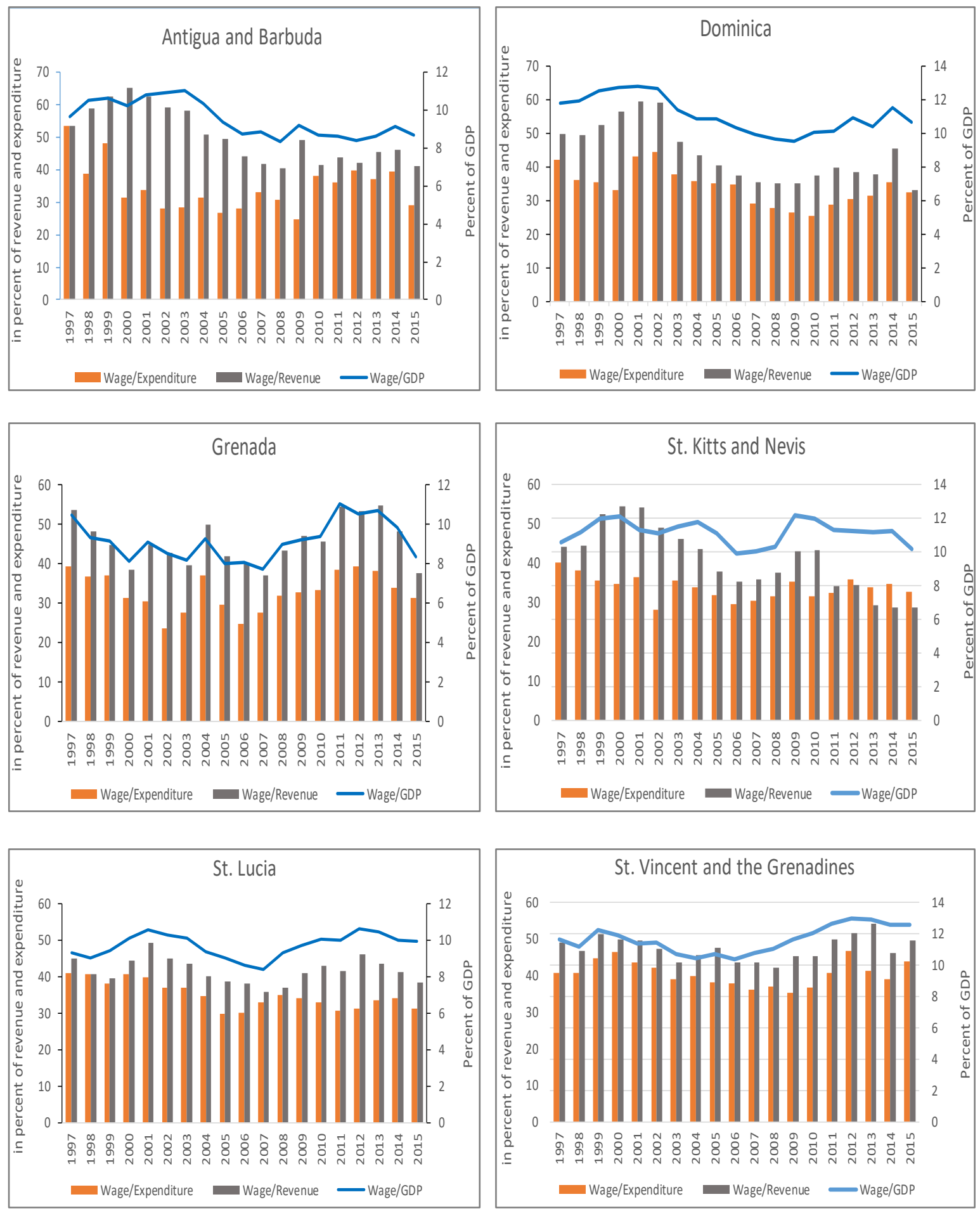

Source: WEO and IMF staff calculations 
In most ECCU countries, wage bill indicators significantly declined from the mid-1990s until the 2009 global financial crisis and rebounded in the ensuing years until 2013 when the recession in many countries ended. In Grenada, St. Kitts \& Nevis, St. Lucia and St. Vincent \& the Grenadines the wage bill during the crisis was as high as in the 1990s (Figure 3). These developments suggest the resilience of government employment amidst the changing economic conditions, notwithstanding reform efforts to contain the size of government and the wage bill (Box 2). The reduction in wage bill indicators post-2013, particularly in Grenada and St. Kitts \& Nevis partially reflects higher-than-potential output growth and increased revenue yields.

We construct Laspeyre indices of the average wage level and of employment to illustrate their relative contribution to the evolution of government wage bills over the 2005 to 2015 period (Figure 4). ${ }^{10}$ In general, the results indicate that changes in nominal average wages have been more dominant than changes in employment. Increases in the nominal price effect in Antigua $\&$ Barbuda, perhaps reflecting hiring at above average wages at the end of the period, offset the overall decline in employment over the decade. In Dominica, Grenada, St. Lucia, and St. Vincent \& the Grenadines the price effect-reflecting wage increases, incremental pay progression and promotions - is significant as it contributed between 73 to 88 percent to the growth in the nominal wage bill. However, in Dominica the restitution of wage price cuts during 2002-2004 also had a significant impact, while in Grenada the wage freeze and attrition policy is discernible at the end of the period. In St. Kitts \& Nevis, the employment effect contributed about 41 percent to nominal wage growth although it stabilized during the earlier part of the fiscal consolidation period (2010 to 2013), when an employment and wage freeze policy was in effect.

Real wage indices suggest wide country variation reflecting differences in pay policies and price levels. In Dominica, real average wage levels grew annually by 4.3 percent in the 9 years to 2015 while that in St. Kitts \& Nevis, St. Lucia and St. Vincent \& the Grenadines grew modestly (between 2.2 and 2.7 percent annually) but remained flat or marginally declined in the other countries over the decade (2005-15). Furthermore, average real wage growth exceeded the growth in real per capita GDP over the comparable period. This implies, ceteris paribus, that government wage growth outpaced productivity growth.

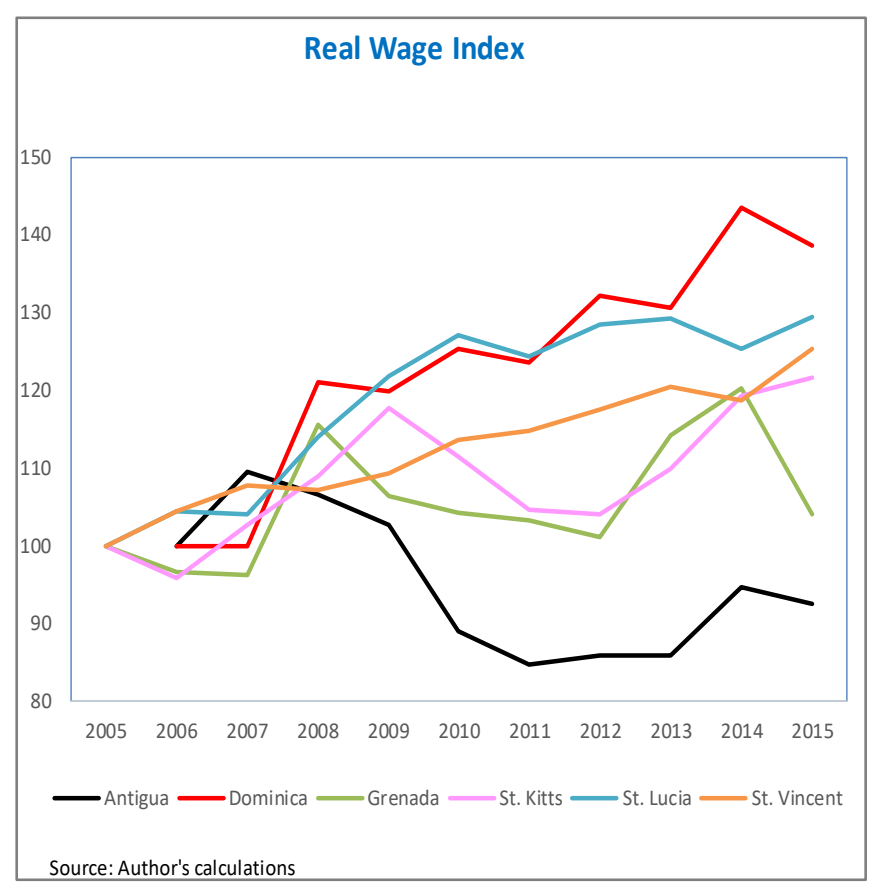

10 The average wage level is obtained by dividing the wage bill by employment. The assessment of Dominica reflects developments from 2007 because of the difficulty in disentangling the employment and price effects prior to that date. Data for Grenada reflects established staff only. 

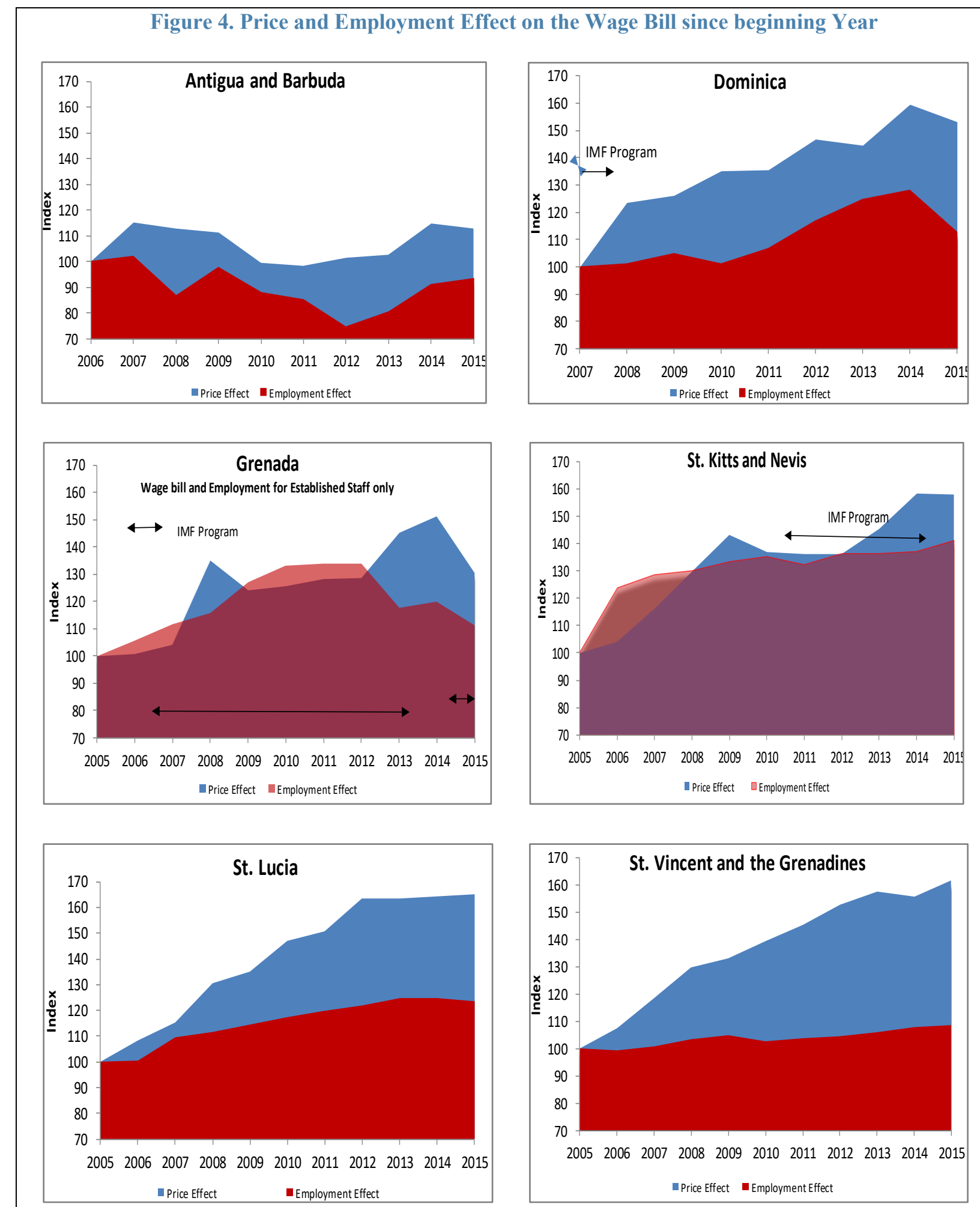

Source: Country authorities and IMF Staff calculations 


\section{Government Employment and Efficiency}

On average ECCU governments in 2015 employed 11.6 percent of the working population. This is similar to findings in IMF (2016a) for advanced countries but is higher than those of emerging markets and LIDCs. Relative to small states, the employment indicator falls within the range of 7.6 percent to 17.2 percent for those countries - The Bahamas, Bhutan, Cyprus, Fiji, Mauritius, Seychelles, and Trinidad \& Tobago for which data was available. ${ }^{11}$

Government employment indicators for Antigua \& Barbuda and St. Kitts \& Nevis, the countries that have the lowest unemployment rates, exceed the regional average. Government employment in most countries steadily increased over the last decade and during the 2009/2012 recession except in Antigua \& Barbuda where the declines resulted from initiatives implemented in 2006 to cut the wage bill and reform the civil service. Since 2014, government employment numbers have declined in Grenada because of their attrition policy rule (Box 2). Generally, governments have been reluctant to reduce staffing when unemployment is high, there are no alternative social support mechanism for the delivery of income support programs or unemployment insurance, and the private sector is unable to generate the levels of employment to absorb surplus labor. This gives rise to the notion

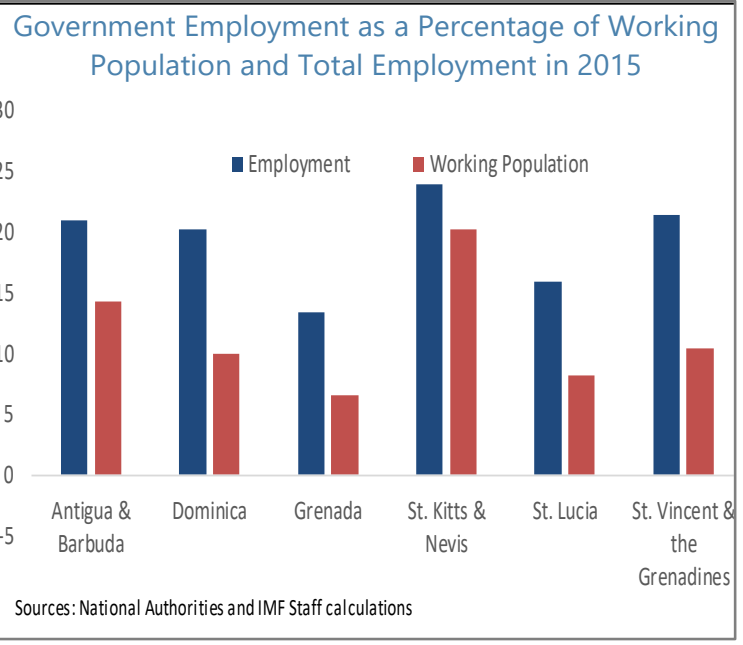

Selected Unemployment Rates

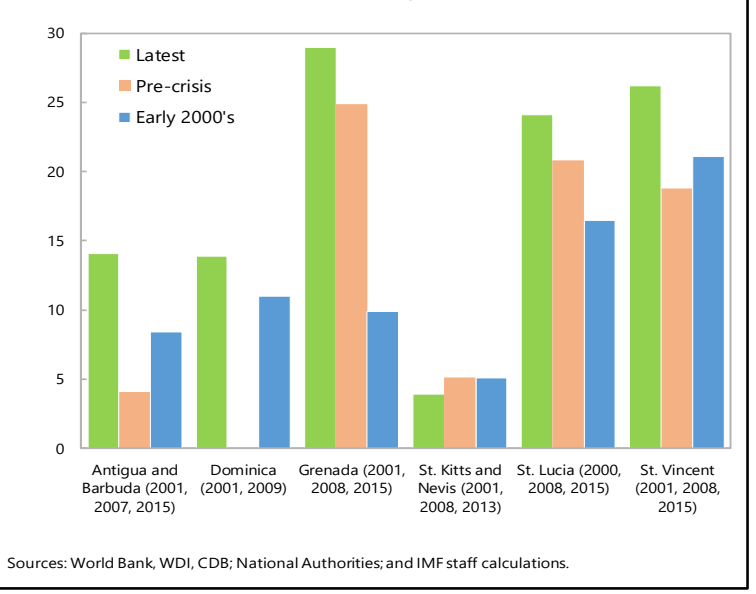
that governments are de facto employers of last resort.

More recently training and apprenticeship programs were implemented as counter cyclical measures as economic conditions and unemployment worsened. Most of these programs are administered by government agencies to address the widening skills mismatch and involve "on-the-job" training, internships, and short-term employment in the public service and private sectors. $^{12}$ The governments of Antigua \& Barbuda and St. Vincent \& the Grenadines include the stipends paid to trainees in the wage bill and trainees are included in a separate category of employment (0.3 percent of GDP and 6 percent of government employment in Antigua \& Barbuda in 2014, respectively). In Grenada, the costs are reflected in Goods and Services while

\footnotetext{
${ }^{11}$ Source - IMF Wage Bill and Government Employment database and selected country data. Data from the Barbados Statistical Office for 2013 shows government employment to population and government employment to labor force ratios of 6 percent and 11.4 percent, respectively.

12 The duration of on-the-job-training in Dominica and Grenada could last two years and is at least one year in St. Vincent \& the Grenadines. In St. Lucia and St. Kitts \& Nevis about 60 percent and 25 percent of the apprentices respectively, worked in the public sector in 2015 .
} 
in the remaining countries, spending is reflected in special projects in capital expenditure and excluded from government employment. The stipends paid to participants should either be categorized as "Compensation of Employees" (with implications for employment and the wage bill) or "Goods and Services" in recurrent expenditures. ${ }^{13}$

Established employees form the core of the public service in most countries, with the notable exception of Antigua \& Barbuda where they represented 50 percent of government employees in 2015. Non-established or contract employees are hired on a temporary basis and have remuneration and benefits packages that do not need to conform to those for established staff. ${ }^{14}$ Their numbers in most ECCU countries, which primarily consisted of semi-skilled workers, have declined over the past decade as part of the regularization of employment practices and a wage bill expenditure cutting strategy. Their composition has also changed in favor of professional, technical and management positions that are better paid than similarly skilled peers in the established cohort. This is indicative of the challenge in attracting and retaining skilled staff. ${ }^{15}$ In Dominica, the number of non-established staff declined significantly from about 47 percent of the public service following reforms in 2006, to about 23 percent. Similarly, in St. Lucia and St. Vincent \& the Grenadines non-established numbers have declined since the late 1990s and are currently about 12 percent while in Grenada and St. Kitts $\&$ Nevis they are 34 percent and 31 percent of government employees, respectively. Governments also employ temporary workers, sometimes referred to as daily-paid workers, for various targeted programs or projects, such as construction or maintenance, whose numbers may be included in the employment statistics. ${ }^{16}$

Senior civil servants across the ECCU region indicate that the problem with government staffing is not so much its size as its composition and distribution (Figure 5). The provision of staffing for some ministries, departments and agencies (MDAs) appear to be "bloated" with unskilled and semi-skilled staff while at the same time there are critical shortages of skilled staff at the technical, professional and middle management levels. Consequently, the quality and effectiveness of institutions in the public service are adversely affected. Available data

\footnotetext{
${ }^{13}$ Payment of emoluments by government or non-government units, which provide the employment or apprenticeship to eligible persons, should be recorded either as a Compensation of Employees, or as use of Goods and Services - Government Financial Statistics Manual 2014 (GFSM 2014, 6.33-34). If there is no employer-employee relationship based on an official employment contract defining the work to be performed and salary, the individuals are not considered to be employees and the government payment for the performed work should be classified as use of Goods and Services. However, when an official employer-employee relationship (contract) exists (like contracts with other employees), the payment to individuals in exchange for the performed work should be classified as Compensation of Employees.

${ }^{14}$ Anthony (1995) indicates that these employees are not public officers since they are not appointed by the delegated authority of the Public Service Commission (PSC) and consequently do not enjoy the constitutional protection extended to public officers who fall within the jurisdiction of the PSC. It is a loophole whereby persons can be appointed and removed from the Public Service without the intervention of the PSCs.

${ }^{15}$ In some instances, governments have hired professional staff on contract basis as a long-term wage expenditure strategy.

${ }^{16} \mathrm{Li}$ and Lafeuillee (2016), also note the creation of temporary jobs by the government of Grenada through targeted public construction projects and highway maintenance ("de-bushing").
} 
indicate that employment pyramid structures have a very wide base reflecting large numbers of unskilled and semi-skilled workers in the civil service. For instance, 2010 data on Antigua \& Barbuda indicate that at the aggregate level about 69 percent of the Civil Service, classified by job category, were clerical, support and semi-skilled staff while professional and technical staff comprised 4 percent and 25 percent, respectively. A less rigorous exercise using government grades of established employees as proxies for skill levels and qualifications suggests that about 44 percent and 43 percent of government established employees in St. Kitts \& Nevis and St. Lucia respectively, are technical and professional staff in $2014 / 15$.

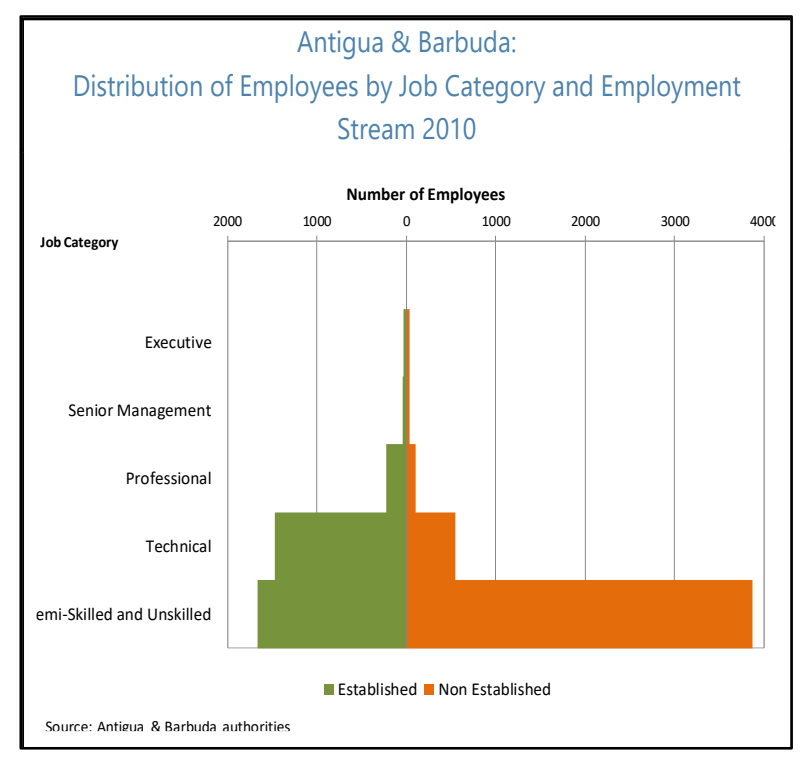

Empirical research comparing the different components of the public service (civil service, education, health, public security and defense) in the ECCU with peer countries or against benchmarks is limited or dated. However, there is some evidence to support the view that the composition and quality of employees in the education and health sector is inadequate and could be contributing to sub-optimal outcomes.

- In 2015, ECCU countries employed more public-school teachers relative to other comparator groupings including Small States, Latin America \& Caribbean, and the OECD - reflected in lower student/teacher ratios (Table 1). ${ }^{17}$ However, the number of trained teachers, particularly in secondary education, was significantly lower and could be contributing to subpar educational outcomes (Box 1).

- In the health sector, Carpio and FullerWimbush (2016) observed increases in the numbers of health workers but continued shortage of nurses and medical specialists in health facilities in the ECCU countries. The number of specialized nurses in the mid2000s (about 1.25 nurses per 1,000 population) was one-tenth the concentration

\begin{tabular}{|c|c|c|c|c|c|}
\hline \multicolumn{6}{|c|}{ Table 2: Selected Indicators on Education in $2015^{\backslash 1}$} \\
\hline & ECCU & $\begin{array}{l}\text { Small } \\
\text { States }\end{array}$ & $\begin{array}{l}\text { Upper } \\
\text { Middle } \\
\text { Income }\end{array}$ & OECD & $\begin{array}{c}\text { Latin } \\
\text { America \& } \\
\text { Caribbean }\end{array}$ \\
\hline \multicolumn{6}{|l|}{ Primary Education } \\
\hline Student/Teacher Ratio & 15.1 & 22.9 & 18.6 & 15.9 & 21.9 \\
\hline Percentage of Trained Teachers & 71.4 & 79.0 & 85.4 & $\ldots$ & 87.9 \\
\hline \multicolumn{6}{|l|}{ Secondary Education } \\
\hline Student/Teacher Ratio & 11.5 & 15.1 & 14.7 & 13.9 & 15.2 \\
\hline $\begin{array}{l}\text { Percentage of Trained Teachers }{ }^{12} \\
\text { Upper Secondary Education }\end{array}$ & 54.7 & $\cdots$ & $\ldots$ & $\ldots$ & 80.4 \\
\hline Student/Teacher Ratio & 11.0 & 13.1 & 15.2 & 13.3 & 14.4 \\
\hline Percentage of Trained Teachers & 53.5 & $\ldots$ & $\ldots$ & $\ldots$ & 79.4 \\
\hline \multicolumn{6}{|c|}{$\begin{array}{l}\text { Source: UNESCO and World Bank } \\
\text { |1 } 2015 \text { or latest data available } \\
\text { 12 ECCU average excludes St. Vincent \& the Grenadines }\end{array}$} \\
\hline
\end{tabular}

${ }^{17}$ Since 2006, the ECCU countries have increased equitable access to secondary education through implementation of universal secondary education which markedly increased classroom sizes and warranted the construction of new secondary schools and hiring of teachers (Hinds, 2007).

(continued...) 
in some OECD countries. ${ }^{18}$ High vacancy positions in the public sector suggest that the demand for nurses exceeds supply (World Bank, 2009). Emigration is a contributory factor in the shortage of trained nurses in the ECCU and wider Caribbean particularly in the provision of primary care. The shortage of nurses has had a tangible impact, together with other contributory factors, on the increasing prevalence of non-communicable diseases (NCDs) which were the leading cause of premature deaths (ranging from 43 to 80 percent) among adults in 2015. ${ }^{19}$ In turn, the ability of countries to meet their key health care service needs, especially NCD prevention and care, improve labor force participation and productivity could be compromised.

- The number of persons employed in public defense and safety has been stable. Police to citizen ratios in the ECCU, which range from 1:110 to 1:190, are high by international standards. Crime statistics, which are under reported, show relative increases in the decade through $2010 .^{20}$ The detection rate for serious crimes generally ranges from $25 \%$ to $40 \%$ of reported crimes and conviction rates are lower. The increases in crime and insecurity has increased the demand for private security to supplement the inadequacy of public security provision. There has been an increase in the number private security firms with greater skills and expertise, in certain respects, than the police (Bishop and Montoute, 2017). In 2011, staffing in these firms relative to the number of police officers was estimated to range between 40 percent in Dominica and St. Vincent \& the Grenadines to 150 percent in St. Kitts \& Nevis. ${ }^{21}$

The World Bank's Government Effectiveness Indicator, a composite of sub-indicators capturing perceptions of public sector performance suggests that government effectiveness has significantly declined in ECCU countries since 2013 but a recovery was evident in Antigua \& Barbuda and St. Kitts \& Nevis in 2015.22 More importantly, it highlights the need to improve government effectiveness particularly in Grenada and St. Lucia where ratings have declined below zero. ${ }^{23}$

\footnotetext{
${ }^{18}$ World Health Organization-Global Health Observatory data repository.

${ }^{19} \mathrm{PAHO} / \mathrm{WHO}$ and CARICOM, Port of Spain Non-Communicable Disease Summit Evaluation, 2016.

${ }^{20}$ Crime statistics cover homicides, shootings, robbery, burglary/break-ins, and rape. The UNDP Citizen Security Survey 2010 measures the extent of victimization in 7 Caribbean countries including Antigua \& Barbuda and St. Lucia, and its variation across individuals and nations. The survey indicates that the spate of crime in many countries is much higher than reported.

${ }^{21}$ Data was unavailable for Antigua and Barbuda.

22 The indicators reflect perceptions of the quality of public services, the quality of the civil service and the degree of its independence from political pressures, the quality of policy formulation and implementation, and the credibility of the government's commitment to such policies. Individual variables from each data source used to construct this measure can be found in Kaufman et al (2010). Changes in methodology and data sources in 2014 negatively affected the country scores. However, these changes were only statistically significant at the 25 percent level for St. Kitts \& Nevis, St. Lucia and St. Vincent \& the Grenadines suggesting that the changes in methodology and data only partially explain the deterioration in that year.

${ }^{23}$ The decline in Grenada also coincides with the governments implementation of its Home-Grown Program of Adjustment and its attrition rule to manage the civil service employment and the wage bill.
} 
Reducing wage bill growth through such measures as recruitment freezes combined with attrition, outsourcing, employment cuts, etc. can reduce costs but will not improve efficiency if key drivers of productivity such as public-sector modernization and skill levels are ignored. For example, notwithstanding the low pupil-toteacher ratios teachers in ECCU countries relative to comparator countries, educational outcomes have been below par and reflect some degree of input inefficiency - insufficient spending on teacher training, teaching materials, new

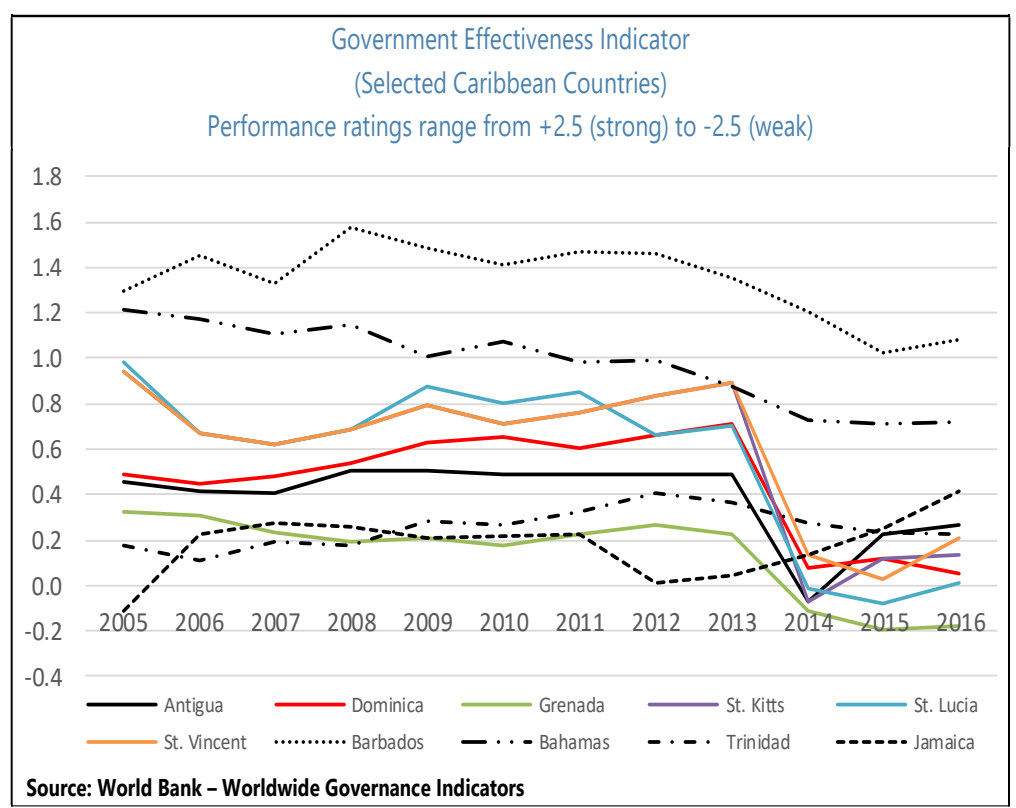
technologies or other non-wage inputs would contribute to better outcomes - see Box 1. Thus, reducing the number of teachers would reduce the wage bill but not necessarily improve educational outcomes unless other inputs were improved.

Rightsizing the composition and distribution of employment in the public service would address some of the efficiency concerns, but there are challenges to overcome. Fiscal space is insufficient to finance comprehensive public service transformation including paying for separation benefits, and training and hiring more qualified staff. The institutional and legal framework of the public administration is inadequate and needs reform and change management systems need to be established to overcome resistance from stakeholders including policy makers and labor unions, particularly where downsizing might be necessary. We elaborate on the institutional and legal framework in Section V. 


\section{Box 1. Assessing Efficiency in Secondary School Education}

Input and output indicators on secondary education (5 years of schooling) in ECCU countries for the 2014-15 academic year (latest available) provide an assessment of cost, performance and efficiency.

- Expenditure on secondary education in terms of total educational expenditure and GDP varies by country. Except Grenada, it is about 40 percent of the allocation of the education budget in ECCU countries. Expenditure in GDP terms is markedly higher in Dominica and St. Vincent \& the Grenadines while Antigua $\&$ Barbuda and St. Kitts \& Nevis are low even when compared to non-ECCU Caribbean countries.

- Input Efficiency indicators. Pupil/teacher ratios for both regular and trained teachers in the ECCU are generally lower than those in other Caribbean economies suggesting that the class sizes are smaller and that students are likely to be taught by trained teachers. The low ratios in St. Kitts \& Nevis and St. Lucia suggests higher-trained teacher input than the other countries with the latter marginally below the average of Advanced Economies. Repetition rates are lower in St. Kitts \& Nevis and St. Lucia relative to other countries, but this partly reflects a policy limiting student repetition in schools. Drop-out rates are relatively low suggesting that a high percentage of children are provided the opportunity of achieving secondary level education.

- Output Quality Efficiency indicators. The percentage of students passing at least 5 Caribbean Secondary Education Certificate (CSEC) subjects is above 50 percent for most ECCU countries. High scores in Grenada and St. Kitts \& Nevis reflect the lower percentage of students registered to sit at least 5 subjects. Pass rates for 5 subjects including Mathematics and English, a benchmark for eligibility for tertiary academic education, are lower, notably in Antigua \& Barbuda and, when adjusted for exam registration, in Grenada and St. Kitts \& Nevis.

- Implied Cost Effectiveness indicator. Costs per student in GDP per capita terms suggests that Antigua \& Barbuda and St. Kitts \& Nevis have the most efficient secondary education system with inefficiencies in Dominica and Grenada more apparent relative to all countries. Costs in GDP per capita for students with pass rates for at least 5 subjects are lower in the ECCU. Addressing shortcomings in the examination results require a close review of inputs, secondary school facilities/infrastructure, education policies, and capacities for education in academic and vocational subjects.

Summary of Key Indicators of Secondary Education in $2014^{1 /}$

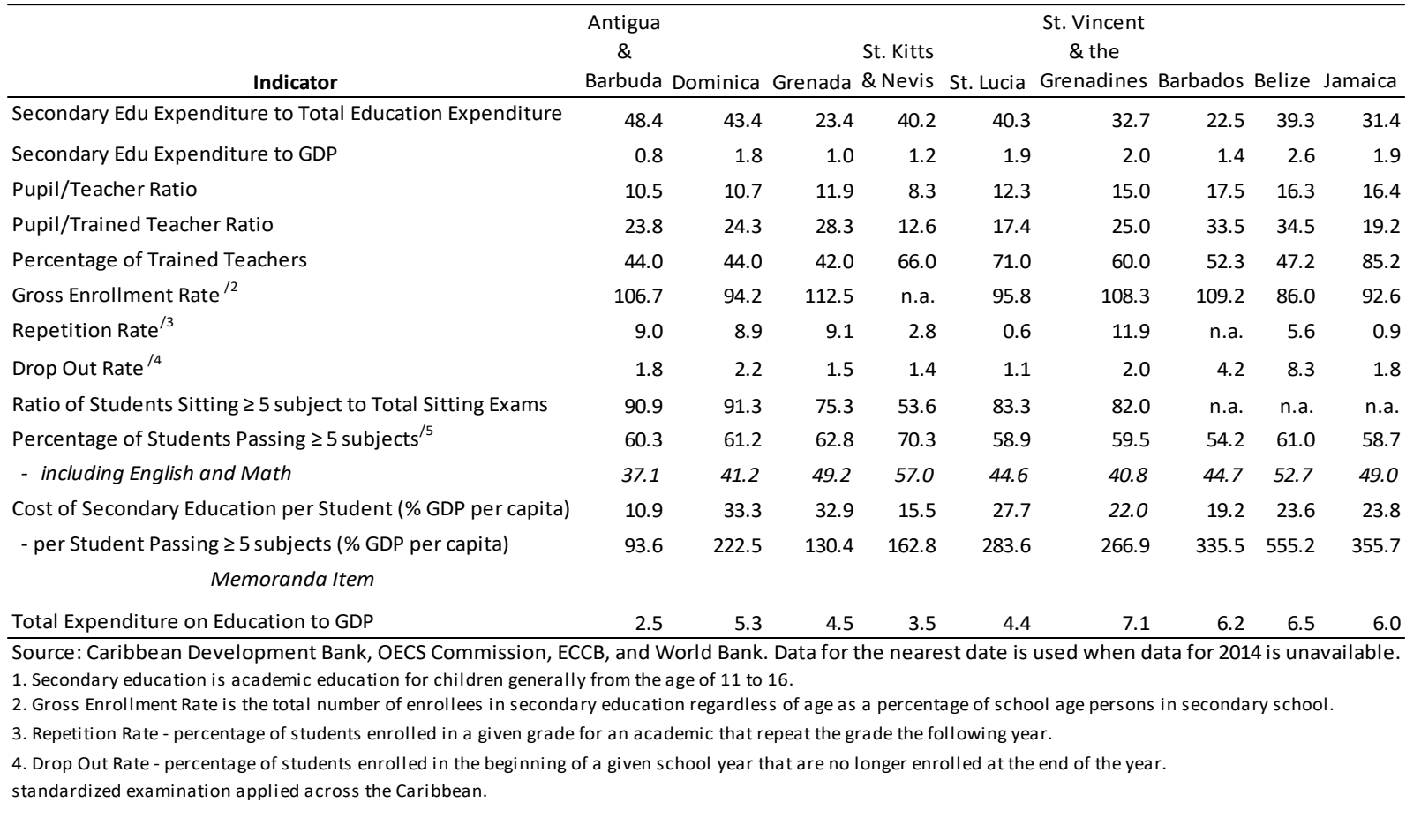




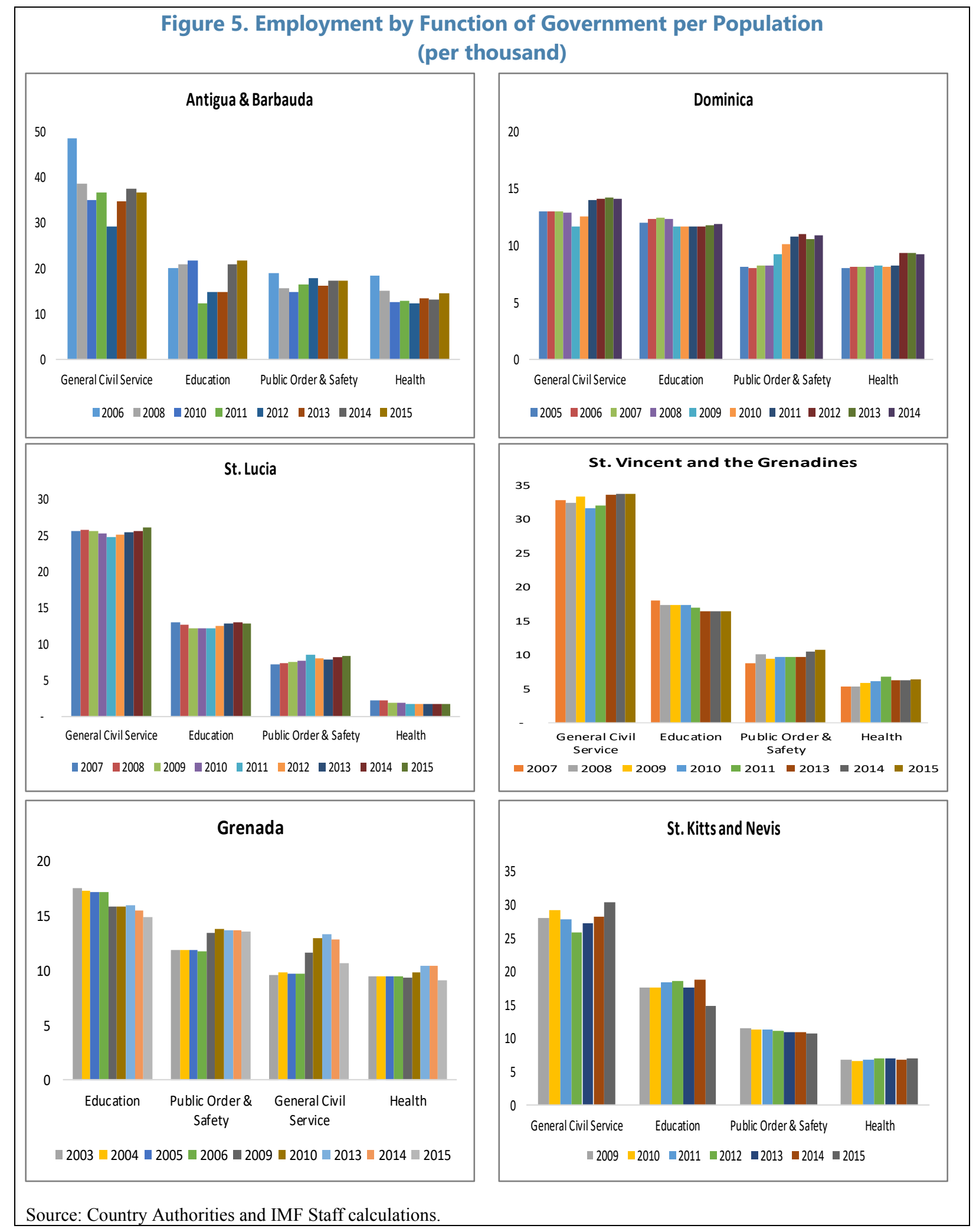

CInternational Monetary Fund. Not for Redistribution 


\section{Compensation}

Wages paid to government employees are higher, on average (10 to 30 percent), than those of the private sector except for those employed in financial intermediation and utility companies (which are 60 to 70 percent higher than the public sector). ${ }^{24}$ This wage premium masks differences in wages among occupational categories and industries in both the public and private sector. ${ }^{25}$ Government employees in semi and unskilled skilled jobs in the public sector are better paid than their private sector counterparts. This situation, when combined with job security in the public sector, likely explains the preponderance of unskilled and semi-skilled workers. However, the remuneration of higher skilled civil servants at the managerial, professional, and technical levels is lower in comparison to those employed in medium to large entities in the private sector, particularly in financial intermediation and utility companies. Allowances have provided pay flexibility but have also made the current remuneration system considerably more complex. The higher compensation premium to the private sector is partially explained by the higher risk of redundancy as well as a reward for higher productivity and longer hours of work relative to the job security provided by government employment.

The lower compensation of higher skilled civil

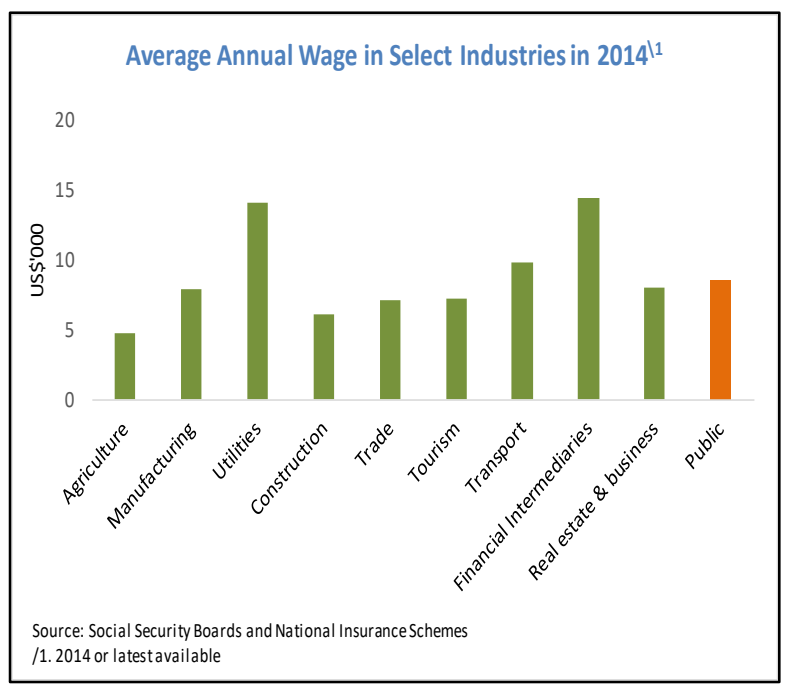

The distribution of Wages Across Select Occupations in Public and Private Sectors in Antigua \& Barbuda

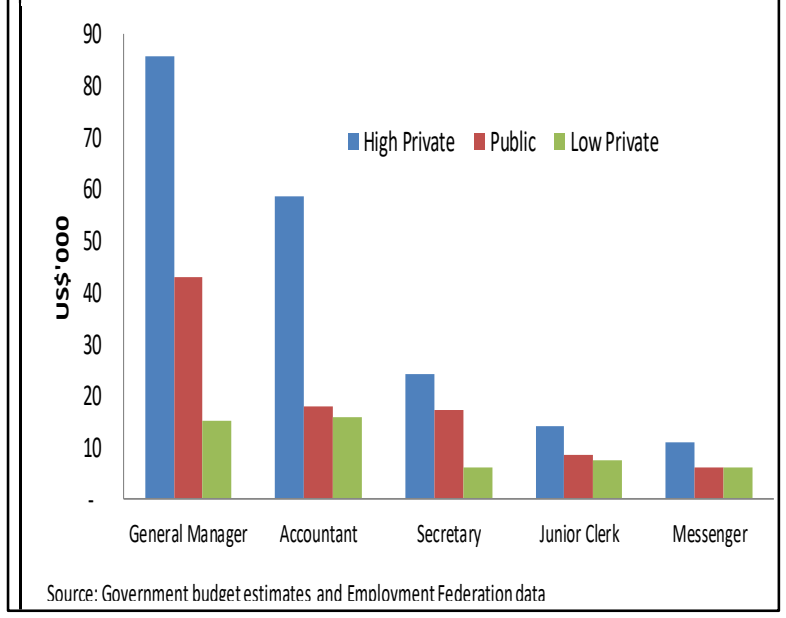
servants relative to their private sector counterparts is compounded by the low compression ratios in the civil service. ${ }^{26}$ The compression ratio between a Permanent Secretary - the most senior civil servant in a government ministry - and

\footnotetext{
${ }^{24}$ For the purposes of comparison, we exclude from the chart the self-employed and persons working in the fisheries, personal and household services, many of whom would be employed at the minimum wage and earning less than those employed in the civil service.

${ }^{25}$ Average wages of persons in public education are lower than those in public administration but higher than those in public health.

${ }^{26}$ Compression is calculated as the ratio of permanent secretary compensation (base salary and allowances) to the lowest public-sector wage rate (base salary only).
} 
an Office Attendant ranged from 5:1 in Dominica to 10:1 in St. Lucia. ${ }^{27,}{ }^{28}$ Schiavo-Campo (1996) indicates that internationally compression ratios range from $3: 1$ to $20: 1$ with a norm of $7: 1 .^{29}$ The longterm outcome is the difficulty of governments in attracting and retaining high-skilled workers as well as a deterioration in public services and the business climate for the private sector.

Inadequate compensation is not the only factor contributing to low retention of skilled staff. Kitchen (1994) World Bank (2001) suggests that opportunities for career advancement, which are largely based on seniority rather than merit, is also a contributory factor. Performance evaluation-based

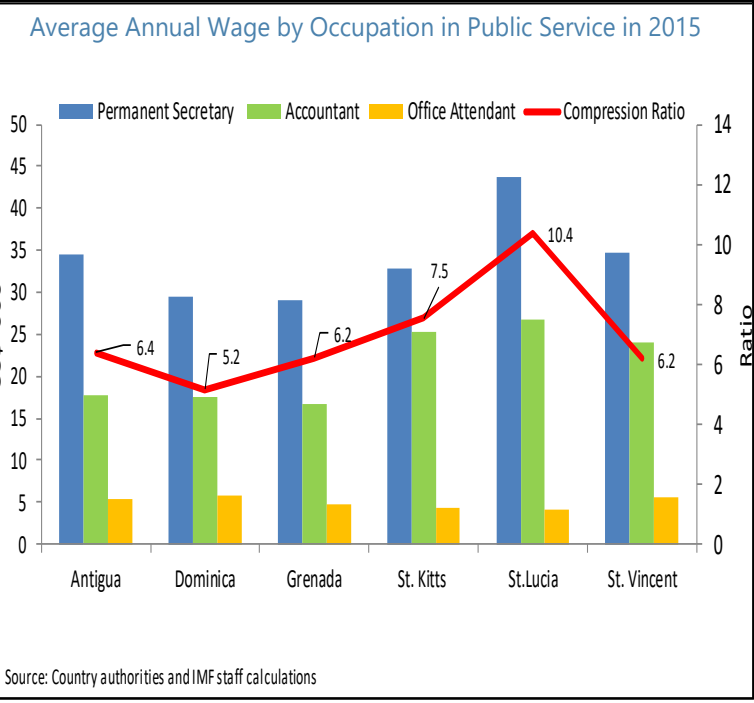

Source: Country authorities and IMF staff calculation systems that are linked to career paths or promotion systems - have not been introduced or are not rigidly applied. Consequently, younger, mid-level civil servants and nurses tend to get frustrated and leave for the private sector or emigrate, particularly after availing themselves of training opportunities.

\section{Drivers}

This section examines the cyclical behavior of wage bill spending in the ECCU and assesses its impact on fiscal discipline. The objective is to understand how business cycles affect wage bill spending and how wage bill spending impacts the government's fiscal position. The data covers the period from 2000 to 2015. This is of sufficient length to span 3 business cycles but not too lengthy as to be subject to structural shifts.

Governments in the post-independence period expanded in a desire to speed up economic and social development. ${ }^{30}$ We use a dynamic, fixed effects panel data model to test the long-run impact of growth on real wage.

$$
y_{i t}=\alpha+\beta y_{i t-1}+\lambda \text { Output }_{i t}+\rho \text { Revenue }_{i t-1}+\varepsilon_{i t}
$$

\footnotetext{
${ }^{27}$ Antigua \& Barbuda civil service establishment structure at the highest senior level distinguishes between administrative and management grades. Permanent Secretaries head the administrative category while Directors/Managers of departments and agencies - Accountant General or Director of Social Security - head the latter. Emoluments of managers are significantly above (12 percent to 114 percent higher) that of Permanent Secretaries. There is a further categorization that is unclassified.

${ }^{28}$ The pay scale in Grenada has not been updated since 1995 while that in St. Lucia was revised in 2011 in favor of the top three tiers of the pay grade. Pay scales in other countries were unchanged in the past decade.

${ }^{29}$ Kitchen (1994) stated that low compression ratios in Guyana (6:1) and Trinidad \& Tobago (8:1) in) in 1992 contributed to the low retention rate among senior managers and led to substantial numbers of poorly skilled professionals, and an "overemployed" junior labor force.

${ }^{30}$ ECCU member countries obtained independence from Britain over a decade commencing with Grenada in 1974 and ending with St. Kitts \& Nevis in 1983.
} 
Where $y_{i t}$ is growth in real wages, Output is real GDP growth, the Revenue-to-GDP ratio denotes whether where the revenue from previous year had affected the wage expenditure in the current year. We control for country and year fixed effects.

\begin{tabular}{|c|c|c|c|}
\hline \multicolumn{4}{|c|}{$\begin{array}{l}\text { Table 2. Model Results: Economic Growth and Wage } \\
\text { Expenditure }\end{array}$} \\
\hline Dependent Variable: & \multicolumn{3}{|c|}{ Real Wage Bill Growth Rate } \\
\hline \multirow[t]{2}{*}{ Explanatory V ariables } & \multicolumn{3}{|c|}{ Coefficients } \\
\hline & Equation 1 & Equation 2 & Equation 3 \\
\hline Real Wage Bill Growth rate & $-0.207^{* * *}$ & $-0.255^{* * *}$ & $-0.264^{* * *}$ \\
\hline & $(0.062)$ & $(0.046)$ & $(0.041)$ \\
\hline Output Gap & & $\begin{array}{c}0.266^{* * *} \\
(0.100)\end{array}$ & \\
\hline Positive Output Gap & & & $\begin{array}{c}0.606^{* * *} \\
(0.177)\end{array}$ \\
\hline Negative Output Gap & & & $\begin{array}{l}-0.084 \\
(0.202)\end{array}$ \\
\hline Outputs & $\begin{array}{c}0.320^{* * *} \\
(0.078)\end{array}$ & & \\
\hline Revenue/GDP ${ }_{t-1}$ & $\begin{array}{l}0.171^{*} \\
(0.085)\end{array}$ & $\begin{array}{l}0.157^{*} \\
(0.081)\end{array}$ & $\begin{array}{l}0.221^{* *} \\
(0.094)\end{array}$ \\
\hline IMF Program & & $\begin{array}{c}-3.4541^{* * *} \\
(1.249)\end{array}$ & $\begin{array}{c}-3.655^{* * *} \\
(1.229)\end{array}$ \\
\hline Elections & & $\begin{array}{l}1.683 * * \\
(2.404)\end{array}$ & $\begin{array}{l}1.537^{*} \\
(0.890)\end{array}$ \\
\hline R-Squared & 0.208 & 0.297 & 0.322 \\
\hline F-statistic & 2.855 & 3.591 & 3.633 \\
\hline Durbin-Watson Statistics & 1.962 & 2.153 & 2.208 \\
\hline Sample Period & & $2000-2015$ & \\
\hline Countries & & 6 & \\
\hline Observations & & 96 & \\
\hline
\end{tabular}

This long-term relationship is supported by an increase in the real wage bill growth rate of 0.32 percentage points for every 1 percentage point in real economic growth over the 2000 to 2015 period (Table 2). ${ }^{31,32}$

The rate of growth in the real public wage bill accelerates by 0.61 percentage points for every 1 percentage point that economies grow above potential. This procyclical relationship is expected and is consistent with the previous result that a positive relationship exists between the wage bill and economic development.

$y_{i t}=\alpha+\beta y_{i t-1}+\lambda$ OutputGap $_{i t}+\delta$ Electionsit $+\gamma \mathrm{IMF}_{\text {Program }} i t+\rho$ Revenue $_{i t-1}+\varepsilon_{i t}$

where $y_{i t}$ is growth in real wages, OutputGap is the output gap expressed as a share of GDP, where the output gap variable is the difference between actual and potential output. Potential output is derived using the Hodrick-Prescott filter to detrend actual output. The Elections and the IMF Program variables are both dummy variables, where Elections represents whether a general election was held in each year and IMF Program captures the numbers of years of exposure of a country under an IMF program (as wage restraint has been a common feature of

\footnotetext{
${ }^{31}$ We employ a dynamic, fixed effects panel data model. This approach is chosen against individual country estimates mainly because of the limited number of countries and short time series data from 2000-15. The econometrics methodology attempts to control for endogeneity so that this estimate considers possible bi-directional causality.

${ }^{32}$ Real GDP per capita as a proxy for economic development was insignificant perhaps reflecting minute changes in population growth over time.
} 
IMF programs in the ECCU region). The Revenue-to-GDP ratio denotes whether the revenue from previous year had affected the wage expenditure in the current year. The error term $\varepsilon_{i t}$ contains country and year fixed effects. The positive and significant coefficient on the gap variable indicates that real wages are procyclical in the ECCU countries (Table 2). However, there is no significant slowdown in the growth of the wage bill during economic downturns, perhaps because of institutional rigidities in the civil service and the reluctance to reduce employment amidst situations of high unemployment. A critical source of rigidity relates to the inherent challenges of reducing the scope of critical public services (national security, health and education) which, in many cases, account for major shares of wage expenditure. Changes in the wage bill are affected by election cycles. During an election year the wage bill is 1.68 percentage points higher than in a nonelection year. The wage bill tends to decline in countries under an IMF program arrangement. Lastly, the results indicate a positive and significant relationship between revenue growth of the previous year and the wage bill.

We regress the fiscal balance, as percentage of GDP, against the wage bill, as a percent of GDP, and two additional explanatory variables - Revenue-to-GDP and GDP per capita. The empirical model used to test the impact of wage expenditure on the fiscal balance is

$y_{i t}=\alpha+\beta y_{i t-1}+\lambda$ WageBillit $+\delta$ Revenue $_{i t}+\gamma$ GDPpercapita $_{i t}+\varepsilon_{i t} \quad$ (3)

where $y_{i t}$ is Fiscal Balance, WageBill is the public wage bill as a share of GDP, Revenue denotes revenues as a ratio of GDP, GDP per capita captures the potential impact of Wagner's Law (economic development leads to growth in public spending), and cit is the error term.

As expected the overall fiscal balance deteriorates significantly when the wage bill increases (Table 3). For every percentage point increase in the wage bill, as a share of GDP, the fiscal balance deteriorates by about 0.64 percentage points. The findings support the view that it is critical to keep the wage bill within fiscally sustainable limits. This would reduce the need for adjustments during fiscal consolidation and strengthen scope for countercyclical properties of fiscal policy.

Notwithstanding worsening fiscal situations, governments have found it challenging to use downsizing as an option of adjustment because (i) they consider the social distress and dislocation caused by enforced redundancies politically unacceptable in societies with high double-digit unemployment rates and lacking adequate social safety

\begin{tabular}{|c|c|}
\hline \multicolumn{2}{|c|}{ Response Variable: Fiscal Balance/GDP ${ }_{t}$} \\
\hline Explanatory Variables & Coefficients \\
\hline \multirow[t]{2}{*}{ Fiscal Balance/GDPt-1 } & $0.291^{* * *}$ \\
\hline & $(0.064)$ \\
\hline \multirow[t]{2}{*}{ Wages Bill/GDP ${ }_{t}$} & $-0.640^{* * *}$ \\
\hline & $(0.256)$ \\
\hline \multirow[t]{2}{*}{ Revenue/GDP ${ }_{t}$} & $0.651^{* * *}$ \\
\hline & $(0.056)$ \\
\hline \multirow[t]{2}{*}{ GDP per Capitat } & $11.333^{* *}$ \\
\hline & $(5.404)$ \\
\hline R-Squared & 0.783 \\
\hline F-statistic & 34.479 \\
\hline Durbin-Watson Statistic & 1.827 \\
\hline Sample Period & $2000-2015$ \\
\hline Countries & 6 \\
\hline Observations & 96 \\
\hline
\end{tabular}
nets and (ii) of concerns that retrenchment would have negative consequences for the retail, financial and other sectors of the economy. The sustainable way forward will largely depend on success in addressing the political economy issues and getting consensus from labor unions, the private sector and civil society. This was successfully achieved in Grenada during its Home-Grown Program supported by the IMF, through the establishment of a Social Compact. 


\section{Wage Bill Management and Public Sector Reforms}

This section reviews and assesses the experiences of ECCU governments with wage bill and public sector reforms over the past two decades. It identifies the elements of success and the critical shortcomings of the institutional and legal framework.

Governments have deployed several short-term policy measures to contain or reduce the wage bill particularly when faced with a fiscal crisis. These include (a) freezing wages; (b) abolishing overtime; (c) attrition while freezing recruitment; (d) stopping or rationalizing wage increments related to pay progression (Box 2), promotions and upgrading of posts; (e) removing employees older than the mandatory retirement age; (f) rationalizing allowances; and (f) cleaning the payroll to eliminate errors and fraud. While such measures may facilitate the achievement of the wage bill target they do not address structural problems.

Box 2. Incremental Pay Progression

The public service has an establishment position-based system that relies on a wage grid to determine pay. Employee positions are mapped to a grade depending on responsibility, knowledge, decision making, communications, and work environment. The grid sets the relativity in pay within (steps) and between grades. Separate but closely aligned grids exist for the teaching service, health and police/defense services. ${ }^{33}$ The pay grid also serves to guide the wage setting for unestablished and temporary employees although they do not move through the annual steps.

Incremental pay progression systems that exist in Antigua \& Barbuda, Dominica, Grenada, St. Kitts \& Nevis and St Vincent \& the Grenadines provide incremental wage increases to established employees as they move through the steps in eligible grades on an annual basis. Annual increments increase the base wage and have a cumulative effect. It is customary for governments offering automatic incremental increases to provision for a two percent increase in wages in their budgets towards anticipated increment pay during the upcoming year. Inadequate personnel records limit the ability of government budget departments to forecast the number of eligible employees and amounts to be paid. Consequently, actual payouts vary depending on the assessment of eligible staff and grades.

Ideally payments of increments should be merit or performance-based rather than automatic. This will provide for better control or smaller increases in the wage bill and could increase employee motivation. However, performance appraisal systems are used sporadically and the practice in Grenada, St. Kitts \& Nevis and St Vincent \& the Grenadines is for an annual automatic award until the maximum step in the grade is reached. Unless the laws and regulations change, increments would continue to automatically accrue at the beginning of each fiscal year. A modified version of the system also exists in Antigua and Barbuda and Dominica. In the former, increments are paid to staff in eligible grades upon the attainment of relevant qualifications. In Dominica it is paid to eligible staff following a favorable annual performance appraisal or attainment of relevant qualification. However, completion of appraisals has been delayed in recent years.

Some countries attempted a second stage of measures to rationalize the public service and wage bill with mixed results (Box 3). These included voluntary separation programs through early retirement and redundancy, compulsory redundancy and outsourcing. Browne (2010) discusses the merits and demerits of each noting that while they facilitate the reduction in employment numbers and the potential to reach the desired level of savings, they also generate additional pension and gratuity costs which are often required up-front. There were other

\footnotetext{
33 These may not have the same number of grades or steps within grades as the public service but in most countries, the
} relative pay is closely aligned. 
challenges which slowed or halted the scope and pace of implementation. For instance, functional and efficiency reviews were required to objectively establish the basis for redundancy and minimize adverse selection, while procedures for the voluntary retirement and redundancy needed to be developed in consultation with employees and trade unions.

Box 3. A Summary of Public Service Reforms in the ECCU since 2005

Civil service reforms (CSRs) have been a central element of government reforms in the ECCU since the late 1980s. Stabilizing or cutting the wage bill was prioritized in many of the reforms because of the urgency of addressing fiscal imbalances. Wider public-sector modernization reform efforts have focused on improving the efficiency of the public service while making it smaller but better paid. Governments, supported by development partners, hoped that the initiatives would also facilitate the development of the private sector and reduce the distorting effects of state intervention on economic activities. The reforms also involved broadening the objectives towards the longer-term goal of creating a government workforce of the right size and skills-mix, and with the right motivation, professional ethos, client focus, and accountability (Verma, 2006). Implementation varied by country and in some cases, were short-lived.

- Antigua \& Barbuda - introduced a voluntary separation and early retirement package (VSEP) in 2006 which cost 1.4 percent of GDP but lowered the wage bill subsequently. A 10 percent wage increase was granted in 2009. Attrition, reduction of overtime allowances, wage freeze, staff reallocations were among the options considered in the 2010-2013 National Economic and Social Transformation plan, which was supported by an IMF arrangement, aimed at reducing the wage bill to 36 percent-of-revenue or 8 percent-of-GDP by 2013. This was not achieved. In 2013, the government initiated a grade reclassification reform aimed at upgrading the teaching service and placing their compensation in line with the rest of the government

- Dominica - instituted wage freezes in 2001 and 2003 and later cut employee remuneration by 5 percent, reduced allowances and overtime pay and laid off many temporary workers $(1,800)$ as well as implemented a hiring freeze in the 2004/06 IMF-supported program. This was a temporary measure as it was agreed, under the memorandum of understanding with Public Service Unions, that remuneration would be restored once the fiscal situation improved. Broad attempts were made at public sector modernization and efficiency through streamlining ministerial functions including outsourcing, commercialization and privatization; modernizing management and strengthening the capacities of senior and middle management for analysis and policy implementation; establishing policies and procedures to improve performance and productivity.

- Grenada - implementation of the 2006-10 public-sector modernization plan was limited to the introduction of corporate planning and Disclosure of Information Policy. A Public Service Management Bill was drafted but not enacted. The government, while under the home-grown adjustment plans supported by IMF programs (2014-17) deployed hiring and wage freezes and an attrition policy. The latter was the main driver of wage bill reductions as employment declined by 10 percent and the wage bill by 2.3 percent of GDP by end-2016. Further, the 2015 Fiscal Responsibility Act limits the wage bill to 9 percent of GDP. The government plans for a comprehensive public-sector modernization during 2017 to 2019.

- St. Kitts \& Nevis - exercised employment restraint and had a wage freeze (2011-14). A payroll audit and functional reviews in three ministries (Education, Health and Public Infrastructure) and Human Resource Management Department were completed in 2015.

- St Lucia - the costs associated with non-established employees were capped in 2009 and operational and efficiency reviews of MDA's initiated. In 2011 the pay grid structure was revised while the system of increments was abolished, and performance assessments of employees implemented. Wage restraint was exercised during fiscal years 2014/15 and 2015/16 when wages were frozen.

- St. Vincent \& the Grenadines - overhauled the public service grading and compensation system through a reclassification exercise in 2007. This exercise resulted in a single spine salary structure grading system that placed all public service employees on a single vertical salary structure.

Not all reforms have resulted in a reduction in the government wage bill. The grade reclassification exercise to a "singlespine" in St Vincent and the Grenadines in 2007, as part of its Government Modernization Program, caused a 6 percent increase in the wage bill as most civil servants were moved into higher pay scales. A similar exercise undertaken with the teachers in Antigua and Barbuda in 2013 had a similar impact. The exercise resulted in a retroactive payment of EC\$2.9 million (0.1 percent of GDP) and effectively led to a net annual increase of the wage bill of the same amount. 
Human resource management capacities and systems to facilitate the reorganization of the civil service and improve its efficiency were also required. The results of these reform efforts were mixed, particularly where financial resources and capacity for implementation were inadequate, even in countries which engaged donors for programs of support. Better outcomes for reforms may be possible when economies are not in a crisis, domestic stakeholders are not apprehensive about being disadvantaged, and civil service functionaries have more time to devote to reforms.

The foregoing suggests critical shortcomings in the legal and institutional framework that make it inadequate for effectively managing the government wage bill and employment. We highlight a few:

- Abolishing staff positions is challenging. ${ }^{34}$ Anthony (1995) indicates that except for Barbados, Jamaica and to a lesser extent Dominica, other Commonwealth Caribbean states have not established clear procedures, whether statutory or otherwise, to regulate the establishment and abolition of public offices. ${ }^{35}$ This limits the ability of governments to "right-size" employment including by moving government functions to the private sector. ${ }^{36}$ While clearly defined procedures do not guarantee the containment of the size of the public service, it is easier in the absence of such statutes for public employment growth to be unregulated.

- Governments do not have the flexibility of reducing employee remuneration to reduce the wage bill. The provisions in ECCU Constitutions make it difficult for member governments to reduce the wage bill by reducing the remuneration (including allowances and increments) of public servants. Grenada's 1973 Constitution prohibits the altering of salaries and conditions of employment following the appointment of public servants. ${ }^{37}$ However, provisions in the Constitutions of Barbados and Trinidad \& Tobago allowed the reduction of emoluments of public sector employees by their respective governments. ${ }^{38}$

- HR and personnel management systems are outdated. The institutional framework provides guaranteed employment tenure, inhibits employee dismissal, impedes the hiring of new

\footnotetext{
${ }^{34}$ http://www1.world bank.org/publicsector/civilservice/surveys.htm.

${ }^{35}$ Anthony (1995) cites the case between a public officer in Dominica and the Government of Dominica in which the Court of Appeal of the Organization of East Caribbean States (OECS) ruled that the government could not abolish an office at its whim. Rather it should have been determined, in consultation with the affected officer, whether the officer could have been appointed to a suitable alternative office barring which, and subject to the powers of removal by the Public Service Commission, provision should be made for the payment of compensation.

${ }^{36}$ A CARICAD (2000) survey of government employees across the six ECCU countries indicate that many government functions would be better located in the private sector or handled at the regional level. Printing and hospital catering and laundry services were examples of services to be provided by the private sector while trade policy coordination and external representation were ranked as the top functions to be performed by regional bodies. At least 40 percent of top and middle management officials indicated that there was duplication and overlap of functions between ministries.

${ }^{37}$ Grenada Constitution 1973, Chapter V, Section 80 (3).

${ }^{38}$ The decision by the government of Trinidad \& Tobago was upheld by the Privy Council when it ruled that Government is authorized to reduce salaries of public officers. The constitution of Barbados was subsequently amended making it impossible to reduce salaries.
}

(continued...) 
staff with the relevant skills but hardly questions the need for vacant job positions. ${ }^{39}$ This encourages practices that reduce competitive pressures and flexibility in staffing. It also provides an incentive to by-pass the regulation and increase employment of nonestablished staff where in many instances there are no fixed salary scales for employees ${ }^{40}$

\section{Considerations for Reforms}

This section presents the main elements of institutional and legal reforms needed to improve wage bill management and public service efficiency in the ECCU.

Managing the wage bill should be considered within the context of civil service reforms aimed at the optimization of service delivery in a fiscally sustainable manner. These should be informed by diagnostic assessments which would provide governments with an economic viewpoint for undertaking functions or private sector involvement and determining the strategies to achieve lowest unit cost whilst maintaining alignment to objectives. Diagnostics assessments should be undertaken periodically, including civil service census, functional reviews, job audits, user surveys, productivity assessments, and HR audits of policies and procedures.

Legislative and institutional reforms are needed to support policy changes and regulate the internal workings of the civil service. These would build on the outcomes of the diagnostics assessments to guide and facilitate the "rightsizing" effort, provision for flexible personnel management practices and HR management to ensure that the required skills are available and increase efficiency. Improving information management systems would support and strengthen personnel management and HR management. ${ }^{41}$ Finally, adopting a position-based system rather than a career-based system would allow greater flexibility in adjusting employment levels and composition.

Reforms of compensation systems and wage grids are needed to attract and retain qualified staff while promoting consistency with fiscal objectives. These can be informed by the diagnostic assessments. Shifting to wage bargaining ahead of the budget formulation process would improve wage bill management and forecasting over the medium term. ${ }^{42}$ Negotiations for wage increases should be guided by macro indicators including GDP and revenue growth, cost of living adjustments, affordability or fiscal sustainability. Performance outcomes as well as pay comparators with the private sector and statutory bodies should also be considered.

\footnotetext{
39 The incremental approach to staffing is implicit in the freeze on "new employment" accompanying adjustment programs, which attempts to control the creation of new jobs, but continues to allow all replacement once there is budget funding. Grenada is an exception. It's 2014 attrition rule generally replaces 3 positions for every 10 positions vacated.

40 Sutton (2008) identifies the conflicting data from country sources, CARICAD, and the World Bank on the number of nonestablishment employees in ECCU countries in the late 1990s which suggests that man power planning was inadequate, and recruitment was expedient and adhoc.

41 The costs of this is sometimes underestimated. It does not refer solely to the purchase of hardware and software but the whole reconstruction/renovation of plants and the reorganization of work flows and business processes.

${ }^{42}$ Grenada's Fiscal Responsibility Law stipulates that salary negotiations should be forward looking to discourage the practice of retroactive payments to Civil Servants.
}

(continued...) 
Notwithstanding the appeal of performance-based pay systems such as increments, they are challenging to implement effectively. The Report of the U.S. Merit System Protection Board (2006) indicates that performance-based systems require a high delegation of responsibility for $\mathrm{HR}$ and budget management but that its impact is ambivalent as it appears to motivate a minority of staff. ${ }^{43}$ Non-monetary incentives such as job content and career development prospects have been found to be better incentives for public employees. Nonetheless, informed, fair and candid assessments are a necessary basis for any incentive system.

Aligning corporate plans of MDAs and performance-based budgeting with national and sectoral strategies would improve efficiency by facilitating better assessments of budget inputs with outputs and results. ${ }^{44}$ Doing so requires the identification of relevant policies, programs and performance indicators, the development of appropriate administrative structures for cost-effective program delivery, as well as management information systems for effective monitoring and evaluation of program implementation. ${ }^{45},{ }^{46}$ Reporting to the public on outcomes and outputs would facilitate accountability and transparency.

Various authors (Naim, 1994;Shihata, 1994; and Slyfeld and Morgan,1994) emphasize the need for a highly consultative process and commitment of many stakeholders - the political directorate (senior members of government and the legislature), managers, staff, and union representatives and the private sector - to establish domestic ownership for the reforms. ${ }^{47} \mathrm{In}$ this regard, Grenada's success with its Committee of Social Partners (represented by the government, churches, labor unions, private sector) in formulating and implementing its 2014/17 Home Grown Program of Adjustment of Fiscal Adjustment and Structural Reforms, is worthy to note. The consultative process will be especially important in managing retrenchment or reducing or removing certain public services which have financial and political implications. The reforms require a significant coordination effort across MDA's and will require the building up of capacities, time for implementation and change management. All stakeholders need to be mindful of this while holding responsible parties accountable.

\footnotetext{
${ }^{43}$ The Report of the U.S. Merit System Protection Board (2006) identifies the following 7 requirements for effective implementation: a culture that supports pay for performance; effective and fair supervisors; a rigorous performance evaluation system; adequate funding; a system of checks and balances to ensure fairness; appropriate training for supervisors and employees; and ongoing system evaluation.

44 See Slyfeld and Morgan (1994) and Sutton (2008) for a discussion on this for Jamaica.

${ }^{45}$ Many countries, for instance, Australia, Ireland, Finland, Sweden and the UK, have engaged in productivity measurement initiatives to track performance trends overtime that may also be useful.

${ }^{46}$ Boyle (2006) identifies the European Central Bank's comparator of public sector, the World Bank's Government Effectiveness Indicator, the OECD Management in Government Comparative Country Data project and the Netherlands Social and Cultural Planning Office study. The international studies acknowledge data limitations and while useful for assessing broad trends caution against their use for country specific reforms.

${ }^{47}$ Slyfeld and Morgan (1994) suggest that Jamaica's 1982 report on government structure, following extensive consultation with private sector interest groups, unions, professionals, and voluntary social organizations was considered reflective of public sentiment on such issues as the need for drastic restructuring of the government apparatus.
} 


\section{Conclusions}

ECCU governments' efforts at wage bill management to restore fiscal stability over the past two decades appear to have achieved some success. Nonetheless, the wage bill as a percentage of GDP, revenue and expenditure are still high and wage and employment policies are needed to restrain excessive growth. The situation could be more of a concern if the adoption of GFS 2014, including proper classification of capital expenditures and temporary work programs, result in larger wage bills.

The composition of employment is skewed in favor of unskilled and semi-skilled employees who are on average better paid than their private sector counterparts. On the other hand, there is a shortage of skilled employees which is adversely affecting the quality of service delivery and the effectiveness of government institutions. This structural problem, while acknowledged in many public-sector reform strategies, has not been sufficiently addressed.

Econometric results indicate that wage bill spending is asymmetric, increasing when economic growth is above potential but is rigid during downturns. Wage bill spending increases during election years but declines when countries are undertaking reforms supported by IMF arrangements. The positive relationship between revenue growth and the wage bill suggests that revenue considerations influence wage bargaining. The results also confirm expectations that the overall fiscal balance deteriorates significantly when the wage bill increases. Consequently, better wage bill management should be a critical component of reform efforts to achieve a more sustainable fiscal balance.

The challenge ahead is to strengthen the legal and institutional framework to improve wage bill management and address inefficiencies in public sector employment and civil service performance. This requires a deeper commitment and implementation of reforms so that governments provide the appropriate services in an affordable way. Reforms of the institutional framework should be informed by diagnostic assessments including prospects to achieve economies of scale and efficiency through greater regionalization of common services. Adequate financial and technical resources are required for implementation. Appropriate indicators are needed to establish clear links between financial allocations and budget performance, to monitor and assess performance and productivity, and to inform wage bargaining and policy. Indicators of government performance should be also published.

Success of the reforms will also require the commitment of the government, civil servants, unions and the private sector. This suggests an iterative process of assessments of strategies as well as reform and policy implementation. It will require the active participation of senior members of government and the legislature as well as the establishment of a highly consultative process to encourage domestic ownership. Additionally, the establishment of reporting mechanisms and clear lines of authority and individual responsibilities for implementation will improve chances of success. Timing is important, and the current period of economic prosperity is likely to provide more fiscal space and traction from stake holders for the implementation of civil service reforms than under crises situations.

The paper also highlights that an improved dataset would facilitate broader research and analysis on the wage management policy framework. Improving public employment data sets would facilitate more analytical work and reporting on wage bill management and labor market structures. It could also allow the broadening of the research into areas including civil service productivity, input efficiency, social welfare systems that can be incorporated in the work programs of HR and labor departments, and Macro Policy Units. 


\section{REFERENCES}

Anthony, Kenny (1995). "Constitutional and Administrative Issues" in CARICAD, Report of a Working Group on Government Reform and Administrative Restructuring in the Caribbean Community. Bridgetown: Caribbean Centre for Development Administration (mimeo).

Atkinson, Sir Tony. (2005). Atkinson review: Final Report. Measurement of government output and productivity for the national accounts. Houndmills, Basingstoke, Hampshire: Palgrave MacMillan. Available at http://www.statistics.gov.uk/about/data/methodology/specific/PublicSector/atkinson/final_re port.asp

Arpaia, Alfonso, et al, 2014, "Government Wages and Labor Market Outcomes", European Commission Economic and Financial Affairs Occasional Paper 190.

Borjas, G. J. "The Wage Structure and the Sorting of Workers into the Government" NBER Working Paper No. 9313, October 2002

Boyle, Richard, 2006. "Measuring Public Sector Productivity: Lessons from International Experience" CPMR Discussion Paper 35, Institute of Public Administration, Ireland.

Bishop, Matthew L., and A. Montoute, 2017. "Private Security in the Caribbean." In Crime, Violence and Security in the Caribbean, edited by M Raymond Izarali, 200-220, New York: Routledge, 2017.

Brown, Deryck R, 2010. "Institutional Development in Small States: Evidence from the Commonwealth Caribbean". Halduskultuur - Administrative Culture 11 (1): 44-65.

Carpio; Carmen and Danielle Fuller-Wimbush, 2016. The Nurse Workforce in the Eastern Caribbean: Meeting the Challenges of Noncommunicable Diseases. Directions in Development - Human Development. The World Bank.

Commonwealth Secretariat, 2002. "Public Sector Reform in Developing Countries: A Handbook of Commonwealth Experiences." Managing the Public Services Strategies for Improvement Services: No.14, edited by Victor Ayeni; Commonwealth Secretariat, London, United Kingdom.

DOI: https://dx.doi.org/10.14217/9781848597754-en

Demekas, Dimitri G., and Z. G. Kontolemis, 1999, "Government Employment and Wages and Labor Market Performance", IMF Working Paper 99/55.

Di Gropello, Emanuela, 2003 "Monitoring Educational Performance in the Caribbean", World Bank Working Paper No. 6, Washington, DC 
Eckardt, Sebastian, and Zachary Mills, 2014, "What Goes Up Must Come Down Cyclicality in public Wage Bill Spending”, Policy Research Working Paper 6760, World Bank, Washington, DC.

Government of Dominica, Position Paper - "Dominica's Experience in Public Sector Reform and Performance Management Systems" Mimeo

Government of Grenada, “Attrition Policy”, Cabinet Conclusion No. 1025 of July 7, 2014.

Hinds, Henry, 2007. Universal Secondary Education in the OECS: Policy and Access, Quality and Rewards. OECS Education Reform Unit (OERU); Organisation of Eastern Caribbean States (OECS)

International Monetary Fund (IMF), 2016a, "Managing Government Compensation and Employment-Institutions, Policies, and Reform Challenges," Washington, DC.

- 2016b, "Case Studies on Managing Government Compensation and Employment Institutions, Policies, and Reform Challenges," Washington, DC.

- 2016c, "The Wage Bill in Burkina Faso-Past Trends and Challenges Ahead," Burkina Faso- Selected Issues, Washington, DC.

Kandil, Magda, et al, 2014, "Labor Market Issues in the Caribbean: Scope to Mobilize Employment Growth”, IMF Working Paper 14/115.

Kaufmann, Daniel, Aart Kraay and Massimo Mastruzzi (2010). "The Worldwide Governance Indicators: A Summary of Methodology, Data and Analytical Issues". World Bank Policy Research Working Paper No. 5430 http://papers.ssrn.com/sol3/papers.cfm?abstract_id=1682130

Kitchen, Richard, 1994 "Compensation Upgrading in Caribbean Public Services: Comparative Needs and Experience. "In Civil service reform in Latin America and the Caribbean: Proceedings of a conference, edited by Shahid A. Chaudhry, Gary J Reid, and Waleed H Malik, 164-75, World Bank Technical Working Paper; no.259. http://elibrary.worldbank.org/doi/abs/10.1596/0-8213-3041-1

OECD, 2005, "Performance-related Pay Policies for Government Employees", OECD Publishing, Paris. DOI:10.1787/9789264007550-en

OECD, 2015a, "Modernizing Government: The Way Forward", in Government at a Glance 2015, OECD Publishing, Paris. DOI: http://dx.doi.org/10.1787/gov_glance-2015-53-en

- 2015b, “Government efficiency", in Government at a Glance 2015, OECD Publishing, Paris. DOI: http://dx.doi.org/10.1787/gov glance-2015-53-en 
OECS, 2014, “OECS Education Statistics Digest 2012 -13”. http://www.oecs.org/edmudocuments/digests/652-oecs-education-statistical-digest-2012-13

PAHO/WHO and CARICOM, 2016, "Accelerating Action on NCDS", Evaluation of the 2007 CARICOPM Heads of Government Port of Spain NCD Summit Declaration,

Perez, Javier J., and A. J. Sanchez, 2010, "Is There a Signaling Role for Public Wages? Evidence for the Euro Area Based on Macro Data", European Central Bank Working Paper 1148.

Saint Christopher and Nevis, Public Service Act 2011, No. 19 of 2011

Saint Lucia, Public Administration Country Profile; 2004. Division for Public Administration and Development Management (DPADM); Department of Economic and Social Affairs (DESA). United Nations.

https://www.monroecollege.edu/uploadedFiles/_Site_Assets/PDF/Public\%20Administration \%20Profile.pdf

Schiavo-Campo, Salvatore, 1996, "Reforming the Civil Service", Finance \& Development, September 1996, Volume 33, Number 3, 10-13, International Monetary Fund, Washington, DC.

Seepersad, Randy, 2017 "Crime, Violence and Public Safety in the Caribbean.” In Crime, Violence and Security in the Caribbean, edited by M Raymond Izarali, 19-52, New York: Routledge, 2017.

Shihata, Ibrahim, 1994 "Administrative Reform in Developing Countries: Some General Observations." In Civil service reform in Latin America and the Caribbean: Proceedings of a conference, edited by Shahid A. Chaudhry, Gary J Reid, and Waleed H Malik, 115-36, World Bank Technical Working Paper; no.259.

http://elibrary.worldbank.org/doi/abs/10.1596/0-8213-3041-1

Slyfield, Marie and Paulette Morgan, 1994 "Downsizing: Jamaica's Experience, 1992-93. "In Civil service reform in Latin America and the Caribbean: Proceedings of a conference, edited by Shahid A. Chaudhry A, Gary J Reid, and Waleed H Malik, 159-64, World Bank Technical Working Paper; no.259. http://elibrary.worldbank.org/doi/abs/10.1596/0-8213$\underline{3041-1}$

Staff Orders for the Public Service of Saint Lucia; 25th August, 1983. http://www.govt.lc/media.govt.lc/www/resources/legislation/stafforders.pdfSt. Lucia, Government of (2000). White Paper on Public Sector Reform. St. Lucia: Office of Public Sector Reform.

Soverall, Wayne, 2015. "Civil Service Performance in the Caribbean." In Public Administration and Policy in the Caribbean, edited by Indianna D. Minto-Coy and Evan M. Berman, 111-41. Boca Raton: CRC Press, Taylor \& Francis Group. 
Statistics New Zealand, "Measuring government sector productivity in New Zealand: a feasibility study http://www.stats.govt.nz/browse for_stats/economic indicators/productivity/measuring-govtproductivity/7-education.aspx

Sutton, Paul, 2008. "Government Reform in the Commonwealth Caribbean: A Review of Recent Experiences." The Centre for International Governance Innovation, Ontario, Canada. Caribbean Paper No. 6. https://www.cigionline.org/publications/2008/10/public-sector-reformcommonwealth-caribbean-review-recent-experiences

UNDP (2012). Caribbean Human Development Report 2012 Human Development and the Shift to Better Citizen Security. New York, NY: UNDP. http://www.undp.org/content/dam/undp/library/corporate/HDR/Latin\%20America\%20and\%20Cari bbean\%20HDR/C_bean_HDR_Jan25_2012_3MB.pdf

U.S Merit System Protection Board, 2006, "Designing an Effective Pay for Performance Compensation System", A Report to the President and Congress of the United States, Washington: U.S Merit System Protection Board.

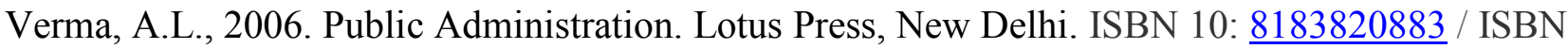
13: $\underline{9788183820882}$

Manning, Nick; Mukherjee, Ranjana; Gokcekus, Omer. 2000. Public Officials and Their Institutional Environment: An Analytical Model for Assessing the Impact of Institutional Change on Public Sector Performance. Policy Research Working Paper; No. 2427. World Bank, Washington, DC.

World Bank, 1997, "The Long March: A Reform Agenda for Latin America and the Caribbean in the Next Decade, edited by Shahid Javed Burki and Guillermo E. Perry, World Bank Latin American and Caribbean Studies

- 2000, Administrative \& Civil Service Reform, Public Officials Surveys, Eastern Caribbean States. http://www1.worldbank.org/publicsector/civilservice/countries/antigua/index.htm

- 2005, "Organization of Eastern Caribbean States - Towards a New Agenda for Growth," Report No. 31863-LAC, World Bank, Washington, DC.

- 2009, The Nurse Labor and Education Market in the English-Speaking CARICOM: Issues and Options for Reform, Report No. 48988-LAC, World Bank, Washington, DC.

- 2011. The Growing Burden of Non-Communicable Diseases in the Eastern Caribbean, World Bank, Washington, DC.

- 2013, Non-communicable Diseases in the Caribbean: The New challenge for Productivity and Growth, Report No. 78596-LAC, World Bank, Washington, DC. 